\title{
Vibrational Analysis of Glutathione
}

\author{
WEILI QIAN and SAMUEL KRIMM
}

Biophysics Research Division and Department of Physics, University of Michigan, Ann Arbor, Michigan 48109

\begin{abstract}
SYNOPSIS
Infrared and Raman spectra have been obtained of crystalline glutathione and its deuterated derivative and interpreted by normal mode analysis. The force field consisted of our empirical force fields for the peptide group and $\mathrm{NH}_{3}^{+}$and $\mathrm{CO}_{2}^{-}$end groups, plus our ab initio force fields for the $\mathrm{CH}_{2} \mathrm{SH}$ and $\mathrm{CH}_{2} \mathrm{COOH}$ moieties. Observed bands are reproduced with an average error of $5 \mathrm{~cm}^{-1}$, demonstrating that the vibrational spectrum of such a complex molecule can be understood in great depth. (C) 1994 John Wiley \& Sons, Inc.
\end{abstract}

\section{INTRODUCTION}

Glutathione, $\gamma$-glutamyl-cysteinyl-glycine, $\gamma$-glucys-gly (GSH), is an important constituent of living cells. ${ }^{1}$ Its major function is to be involved enzymatically in the reduction of hydrogen peroxide and other peroxides, and in general to protect cell components against oxidation. ${ }^{1,2}$

GSH has therefore been the subject of much structural and spectroscopic studies. The crystal structure was first reported by Wright ${ }^{3}$ and subsequently redetermined to higher accuracy by Görbitz. ${ }^{4}$ Infrared and Raman spectra have been recorded, ${ }^{5}$ but no detailed assignments have been made. Conformational and dynamic properties have been studied by $\mathrm{nmr},{ }^{6}$ and quantum mechanical calculations of conformation have been attempted. ${ }^{7}$

Our aim was to provide a detailed analysis and assignment of the vibrational spectrum of the crystalline form of GSH. This can enable a deeper understanding of spectra-structure correlations for other structural states of GSH. We have performed normal mode calculations on GSH and its $\mathrm{N}, \mathrm{S}$, and $\mathrm{O}$ deuterated derivative, GSD, and compared these results with ir and Raman spectra of these compounds. The force field was based on our empirical force fields for the peptide chain ${ }^{8}$ and $\mathrm{NH}_{3}^{+}$and $\mathrm{CO}_{2}^{-}$end groups, ${ }^{9-11}$ and on ab initio force fields for the Cys $\mathrm{CH}_{2} \mathrm{SH}^{12}$ and Gly $\mathrm{CH}_{2} \mathrm{COOH}^{13}$ parts of the molecule. The good agreement obtained between

Biopolymers, Vol. 34, 1377-1394 (1994)

(C) 1994 John Wiley \& Sons, Inc.

CCC 0006-3525/94/101377-18 observed and calculated frequencies not only validates the empirical peptide force field, ${ }^{8}$ as did previous calculations on peptides, ${ }^{9-11}$ but it demonstrates that the vibrational spectrum of a molecule , as complex as GSH can be understood in great depth.

\section{EXPERIMENTAL PROCEDURES}

GSH was obtained from Sigma Chemical Co. We assume that this polycrystalline material has the same structure as the only reported crystal structure of GSH. ${ }^{3,4}$ The deuterated derivative was prepared by dissolving GSH in $\mathrm{D}_{2} \mathrm{O}$, evaporating the solution in vacuo for $24 \mathrm{~h}$ and repeating the procedure until the NH and SH stretch bands disappeared in the Raman spectrum.

Infrared spectra, at $2 \mathrm{~cm}^{-1}$ resolution, were obtained on $\mathrm{KBr}$ pellets, using a Bomem DA-3 FTIR spectrometer, and are shown in Figure 1. Raman spectra, at $2 \mathrm{~cm}^{-1}$ resolution, were obtained on the powder, using a Spex 1403 spectrometer and $\mathrm{Ar}^{+}$ laser $514.5 \mathrm{~nm}$ excitation, and are shown in Figure 2.

\section{NORMAL MODE CALCULATIONS}

\section{Structure}

The unit cell of GSH is orthorhombic, with $a=5.622$ $\AA, b=8.781, \AA$, and $c=28.023 \AA$, the space group is $\mathrm{P} 22_{1} 2_{1} 2_{1}$, and $Z=4 .{ }^{4}$ The molecular packing is shown in Figure 3. The molecules have fractional 

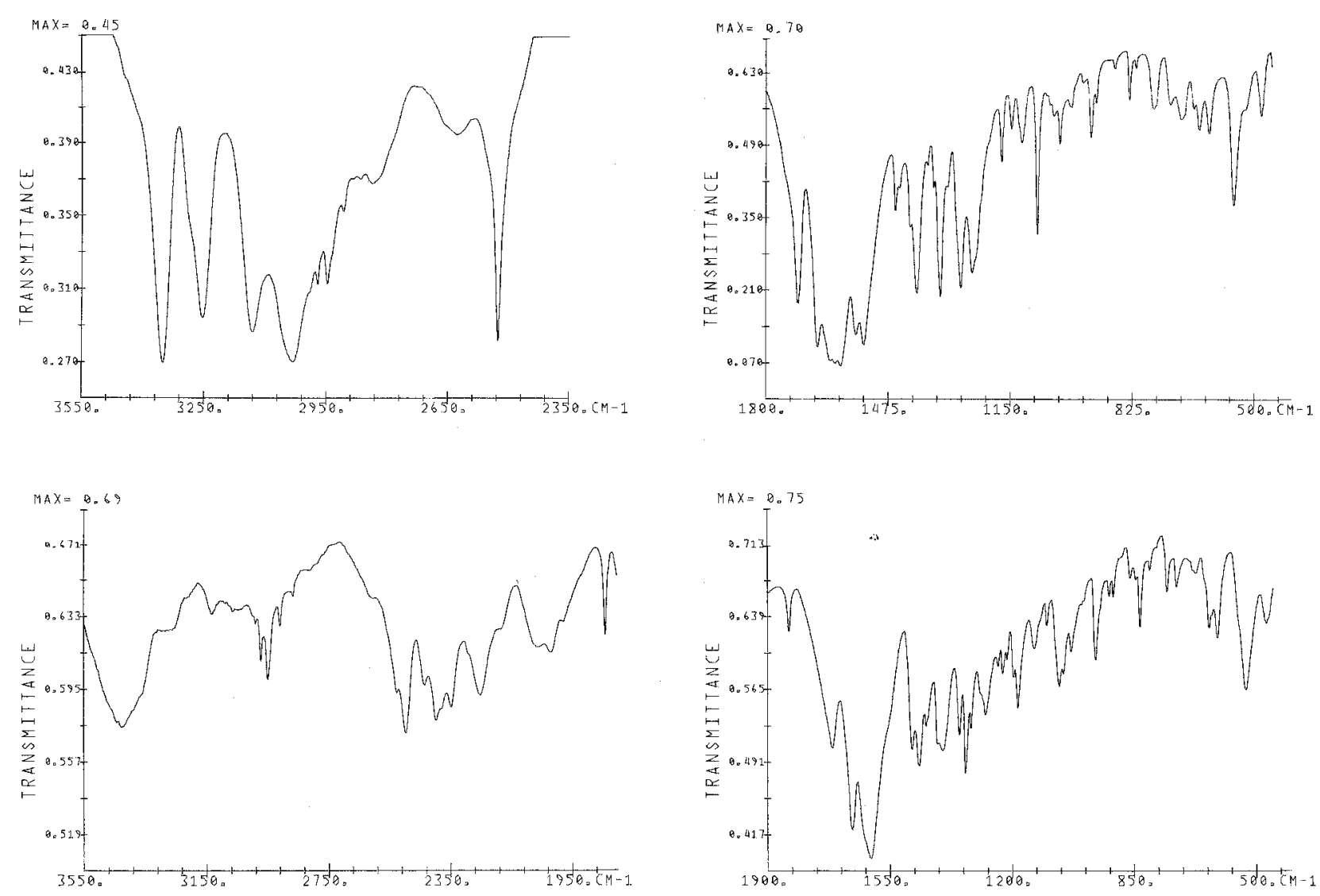

Figure 1. Infrared spectra of (a) crystalline glutathione (upper) and (b) crystalline glutathione-ND, SD, OD (lower).

coordinates of $(x, y, z),(1.5-x, 1-y, 0.5+z)$, $(1-x,-0.5+y, 0.5-z)$, and $(-0.5+x, 1.5-y$, $1-z$ ). Molecules 2, 3, and 4 are related to molecule 1 by screw rotations about the $z$ axis at $\left(\frac{3}{4}, \frac{1}{2}, 0\right)$, about the $y$ axis at $\left(\frac{1}{2}, 0, \frac{1}{4}\right)$, and about the $x$ axis at $\left(0, \frac{3}{4}, \frac{1}{2}\right)$, respectively. The unit cell vibrations belong to four symmetry species, $A, B_{1}, B_{2}$, and $B_{3}$, the symmetry coordinates of each species being linear combinations of the local symmetry coordinates with coefficients $(1,1,1,1),(1,1,-1,-1),(1,-1$, $1,-1)$, and $(1,-1,-1,1)$. The A species modes are only Raman active; the $\mathrm{B}$ species modes are ir and Raman active.

The structure of an individual molecule, shown in Figure 4, was based on that in the crystal. The dihedral angles were those of the crystal structure, although the peptide groups in the main chain were given standard bond lengths and angles ${ }^{8}$ in order to be initially consistent with the empirical force field. ${ }^{8}$ For this reason the peptide groups were also kept planar (one dihedral angle deviates significantly from planarity, $\mathrm{C} 7 \mathrm{C} 8 \mathrm{~N} 10 \mathrm{C} 11=-167.0^{\circ}$, while the other is nearly planar, $\mathrm{C} 11 \mathrm{C} 14 \mathrm{~N} 16 \mathrm{C} 17=-176.8^{\circ}$; the assumption of planarity in the former was found to have no significant effect on the normal mode frequencies). The geometry of the $\mathrm{NH}_{3}^{+}$and $\mathrm{CO}_{2}^{-}$ end groups was the same as before ${ }^{9-11}$ namely N1$\mathrm{H}^{+}=1.037 \AA, \mathrm{C} 3-\mathrm{O}^{-}=1.249 \AA$, angles about $\mathrm{N} 1$ tetrahedral, $\mathrm{C} 2 \mathrm{C} 3 \mathrm{O} 4=117.2^{\circ}$, and $\mathrm{O} 4 \mathrm{C} 3 \mathrm{O} 5$ $=125.6^{\circ}$. Consistent with the $\mathrm{x}$-ray structure, $\mathrm{N} 1 \mathrm{CCO} 4=-18.6^{\circ}$ and $\mathrm{N} 1 \mathrm{CCO} 5=161.5^{\circ}$. The geometries of the Cys and Gly end groups were taken from the ab initio calculations. The crystal structure shows that $\mathrm{NCCS}=69.95^{\circ}$ and $\mathrm{CCSH}=88.65^{\circ}$ for the Cys side chain, corresponding to a $\mathrm{B}$ conformation ${ }^{14}\left(\mathrm{C}^{\alpha} \mathrm{C}^{\beta} \mathrm{SH} \sim 90^{\circ}\right)$, with geometric parameters of ${ }^{12} \mathrm{C} 11 \mathrm{C} 12=1.539 \AA, \mathrm{CS}=1.832 \AA, \mathrm{SH}$ $=1.327 \AA, \mathrm{CCS}=112.7^{\circ}$, and $\mathrm{CSH}=97.7^{\circ}$. For the Gly structure $^{13}$ the parameters are CO19 $=1.200 \AA$, $\mathrm{CO} 20=1.308 \AA, \mathrm{O} 20 \mathrm{H}=0.966 \AA, \mathrm{CCO} 19=114.4^{\circ}$, and $\mathrm{O} 19 \mathrm{CO}=122.6^{\circ}$. The hydrogen-bond system is very complex, all potential groups being involved in the three-dimensional hydrogen-bond network. All of the pendant atoms were included in the normal mode calculation, and the geometric parameters of these hydrogen bonds are given in Table I. 

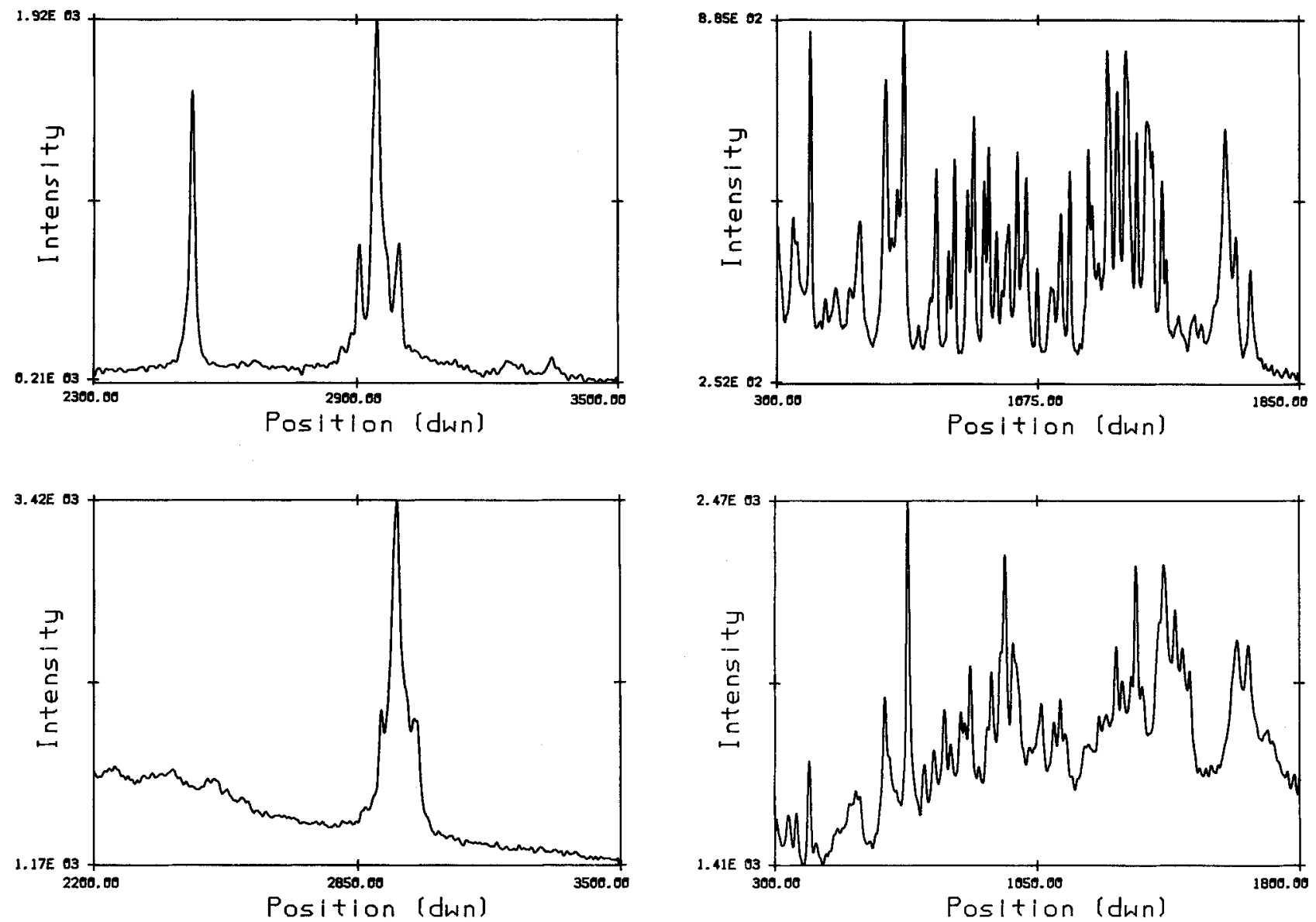

Figure 2. Raman spectra of (a) crystalline glutathione (upper) and (b) crystalline glutathione-ND, SD, OD (lower).

\section{Force Field}

The force field used in the GSH normal mode calculation consisted of a combination of force fields for the five components of the structure: empirical force fields for the peptide chain, the $\mathrm{NH}_{3}^{+}$and $\mathrm{CO}_{2}^{-}$end groups, and the $\mathrm{C}^{\beta} \mathrm{H}_{2} \mathrm{C}^{\gamma} \mathrm{H}_{2}$ segment of the Glu residue, and ab initio force fields for the $\mathrm{CH}_{2} \mathrm{SH}$ side chain of Cys and the $\mathrm{CH}_{2} \mathrm{COOH}$ end group of Gly.

The use of empirical force fields for the peptide chain ${ }^{8}$ is determined by the fact that these are the best that are presently available. Nevertheless, they suffer from limitations that must somehow be dealt with. Besides the lack of explicit conformation dependence of the force constants, perhaps the most serious problem is the dependence of certain important force constants, such as $\mathrm{N}-\mathrm{H}$ stretch (s) $\mathrm{C}=\mathrm{O} \mathrm{s}, \mathrm{O} \cdots \mathrm{H} \mathrm{s}$, and $\mathrm{NH}$ in-plane (ib) and outof-plane (ob) bends, on the hydrogen-bond strengths. To deal with this problem, we assume that, as clearly confirmed by ab initio calculations, ${ }^{15}$ the stretching force constants vary roughly inversely with their respective bond lengths and the bending force constants vary roughly directly with the hydrogen-bond strength. Starting with the empirical values, ${ }^{8}$ these force constants were then refined by least-squares fitting in accord with the above principles.

The force constants for the $\mathrm{C}_{7} \mathrm{H}_{2}-\mathrm{C} 8 \mathrm{O}$ and

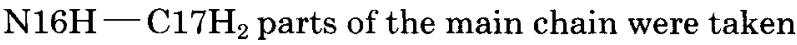
from those for polyglycine $I,{ }^{8}$ while those for the $\mathrm{N} 10 \mathrm{H}$ through $\mathrm{C} 14 \mathrm{O}$ part of the chain were taken from those for $\beta$-poly (L-alanine) ${ }^{8}$ The $\mathrm{N}-\mathrm{H} \mathrm{s}$ constants were determined by fitting to the two clearly assignable $\mathrm{N}-\mathrm{H}$ s bands in the ir spectrum, and their values were consistent with the expectation ${ }^{15}$ that the larger force constant should be associated with the shorter $\mathrm{N}-\mathrm{H}$ bond length, i.e., weaker hydrogen bond $(\mathrm{N} 10 \mathrm{H}=0.818 \AA, \mathrm{N} 16 \mathrm{H}$ $=0.905 \AA$ ). The $\mathrm{C}=\mathrm{O}$ s constants were determined from their bond lengths $(\mathrm{C} 8 \mathrm{O}=1.230 \AA, \mathrm{C} 14 \mathrm{O}$ $=1.245 \AA$ ) according to a previously observed dependence. ${ }^{11}$ The $\mathrm{O} \cdots \mathrm{H}$ s force constants were ob- 


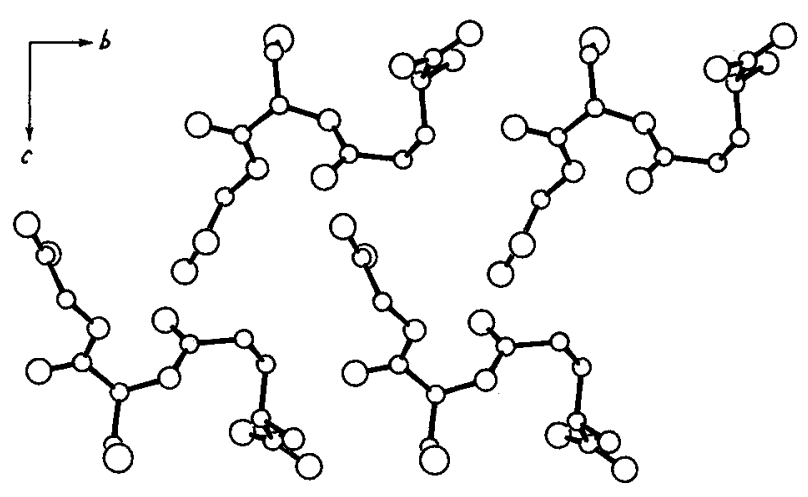

Table I Geometric Parameters ${ }^{\mathrm{a}}$ of Hydrogen Bonds of Glutathione

\begin{tabular}{|c|c|c|}
\hline Hydrogen Bond & $\begin{array}{l}\mathrm{H} \cdots \mathrm{O} \\
\mathrm{O} \cdots \mathrm{H}\end{array}$ & $\begin{array}{l}\mathrm{X}-\mathrm{H} \cdots \mathrm{O} \\
\mathrm{C}-\mathrm{O} \cdots \mathrm{H}\end{array}$ \\
\hline $\mathrm{N} 1 \mathrm{H} 1 \cdots \mathrm{O} 4$ & 2.09 & 151.3 \\
\hline $\mathrm{N} 1 \mathrm{H} 2 \cdots \mathrm{O} 15$ & 1.98 & 146.0 \\
\hline N1H3 $\cdots$ O5 & 1.96 & 157.8 \\
\hline $\mathrm{N} 10 \mathrm{H} \cdots \mathrm{O} 5$ & 2.14 & 161.4 \\
\hline $\mathrm{N} 16 \mathrm{H} \cdot \mathrm{O} 019$ & 2.10 & 142.7 \\
\hline $\mathrm{O} 20 \mathrm{H} \cdots \mathrm{O} 9$ & 1.84 & 159.5 \\
\hline $\mathrm{S} 13 \mathrm{H} \cdots \mathrm{O} 4$ & 2.34 & 159.9 \\
\hline $\mathrm{C} 3 \mathrm{O} 4 \cdots \mathrm{H} 1 \mathrm{~N} 1$ & 2.09 & 147.8 \\
\hline $\mathrm{C} 14 \mathrm{O} 15 \cdots \mathrm{H} 2 \mathrm{~N} 1$ & 1.98 & 130.8 \\
\hline $\mathrm{C} 3 \mathrm{O} 5 \cdots \mathrm{H} 3 \mathrm{~N} 1$ & 1.96 & 106.2 \\
\hline $\mathrm{C} 3 \mathrm{O} 5 \cdots \mathrm{HN} 10$ & 2.14 & 153.8 \\
\hline $\mathrm{C} 18 \mathrm{O} 19 \cdots \mathrm{HN} 16$ & 2.10 & 138.8 \\
\hline $\mathrm{C} 8 \mathrm{O} 9 \cdots \mathrm{HO} 20$ & 1.84 & 112.8 \\
\hline $\mathrm{C} 3 \mathrm{O} 4 \cdots \mathrm{HS} 13$ & 2.34 & 136.1 \\
\hline
\end{tabular}

a Lengths in Ångstrom, angles in degrees.

modes, and resulted in the expected relative values. The NH ob force constant for the Cys residue, which would normally be larger, ${ }^{8}$ was given the same value as that for the Gly residue because of its weak hydrogen bond. The values of all these force constants, as well as some others that needed small adjustments, are given in Table II.

Our previous studies of the $\mathrm{NH}_{3}^{+}$and $\mathrm{CO}_{2}^{-}$end tained from a relationship relating the value of this force constant to $\mathrm{d}(\mathrm{O} \cdots \mathrm{H}),{ }^{16}$ which was based on values refined for $\alpha$ - and $\beta$-poly (L-alanine). ${ }^{8}$ The $\mathrm{NH}$ ib force constants were refined to the amide II

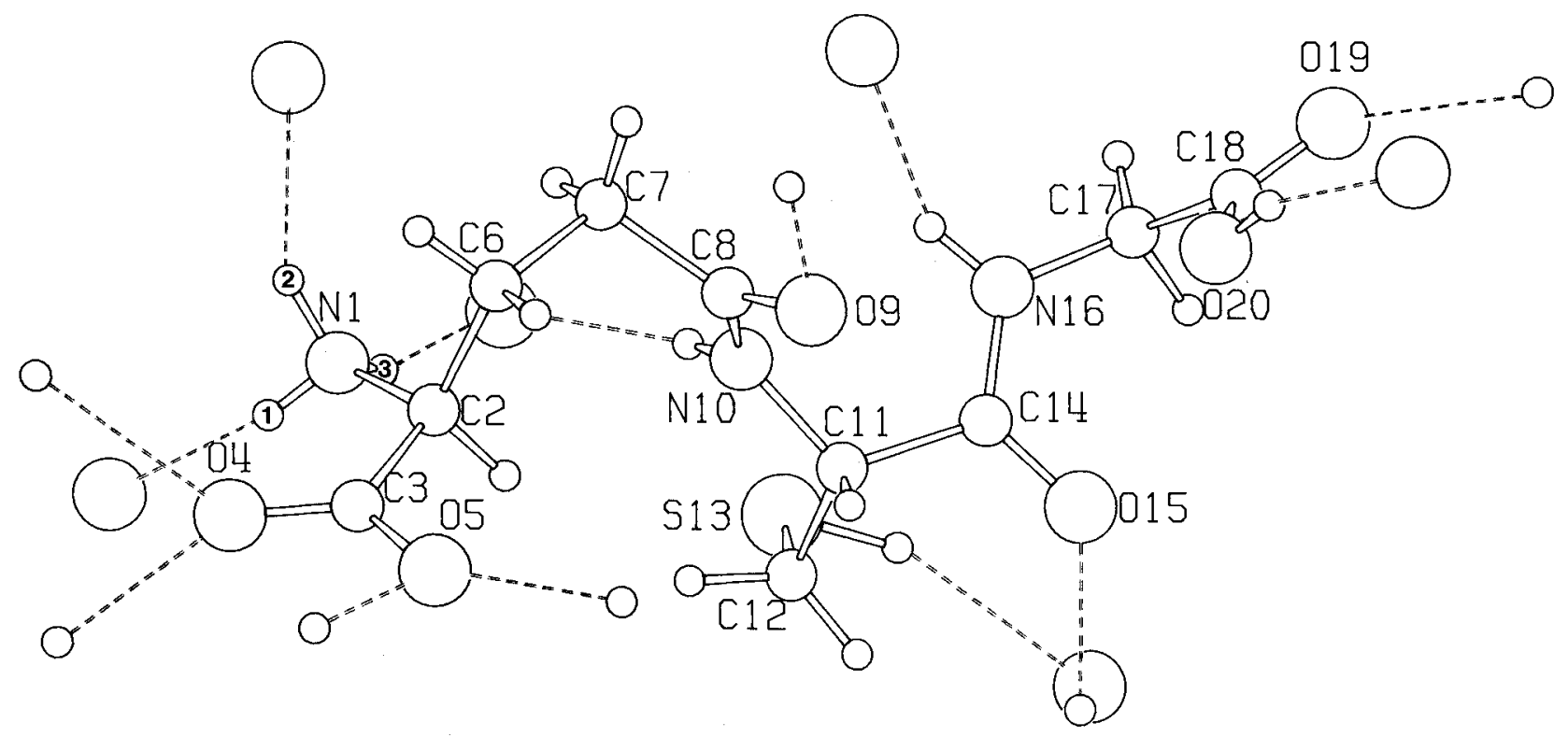

Figure 4. Molecular structure and atom numbering of glutathione, including intermolecular hydrogen bonds (broken lines). 
Table II Modified Force Constants for Glutathione Force Field

\begin{tabular}{|c|c|c|c|c|c|}
\hline Group & Force Constant ${ }^{a}$ & Value $^{\mathrm{b}}$ & Group & Force Constant ${ }^{a}$ & Scale Factor ${ }^{c}$ \\
\hline \multirow[t]{15}{*}{ Peptide $^{d}$} & $\mathrm{~N} 10 \mathrm{H}$ & 6.158 & $\mathrm{CH}_{2} \mathrm{SH}^{\mathrm{g}}$ & $\mathrm{SH}$ & 0.947 \\
\hline & $\mathrm{N} 16 \mathrm{H}$ & 5.827 & 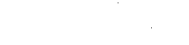 & $\mathrm{CS}$ & 0.953 \\
\hline & $\mathrm{C} 8 \mathrm{O}$ & 9.646 & & $\mathrm{CC}$ & 0.944 \\
\hline & $\mathrm{C} 14 \mathrm{O}$ & 9.222 & & $\mathrm{CCS}$ & 0.974 \\
\hline & $\mathrm{C8N}$ & 6.678 & & $\mathrm{CSH}$ & 0.908 \\
\hline & $\mathrm{C} 14 \mathrm{~N}$ & 6.678 & & & \\
\hline & $\mathrm{N} 10 \mathrm{H}$ ob & 0.129 & $\mathrm{CH}_{2} \mathrm{COOH}^{\mathrm{h}}$ & C18019 & 1.0278 \\
\hline & $\mathrm{N} 16 \mathrm{H} \mathrm{ob}$ & 0.129 & & NC17H & 1.0401 \\
\hline & $\mathrm{C} 8 \mathrm{O}$ ob & 0.530 & & $\mathrm{CCO} 20$ & 1.1225 \\
\hline & $\mathrm{C} 140 \mathrm{ob}$ & 0.560 & & OCO & 0.9337 \\
\hline & N10C11 & 4.310 & & $\mathrm{COH}$ & 0.510 \\
\hline & $\mathrm{C} 11 \mathrm{C} 14$ & 4.700 & & OH..O & 0.2547 \\
\hline & $\mathrm{H}^{\alpha} \mathrm{C}^{\alpha} \mathrm{C}^{\beta}$ & 0.5486 & & & \\
\hline & $\mathrm{NC} 2 \mathrm{H}, \mathrm{C} 3 \mathrm{C} 2 \mathrm{H}$ & 0.0324 & & & \\
\hline & $\mathrm{NC} 11 \mathrm{H}, \mathrm{C} 14 \mathrm{C} 11 \mathrm{H}$ & 0.0525 & & & \\
\hline \multirow[t]{5}{*}{$\mathrm{CC}^{\mathrm{e}} \mathrm{C}^{\mathrm{a}}$} & $\mathrm{C} 2 \mathrm{C} 6$ & 5.126 & & & \\
\hline & $\mathrm{C} 6 \mathrm{C} 7$ & 4.247 & & & \\
\hline & C7C8 & 4.534 & & & \\
\hline & $\mathrm{CC} 7 \mathrm{C}$ & 1.240 & & & \\
\hline & CC6C & 1.240 & & & \\
\hline \multirow[t]{7}{*}{ Hydrogen bonds ${ }^{f}$} & $\mathrm{~N} 1 \mathrm{H} 1 \cdots \mathrm{O} 4$ & 0.055 & & & \\
\hline & $\mathrm{N} 1 \mathrm{H} 2 \cdots \mathrm{O} 15$ & 0.079 & & & \\
\hline & N1H3 $\cdots O 5$ & 0.084 & & & \\
\hline & $\mathrm{N} 10 \mathrm{H} \cdots \mathrm{O} 5$ & 0.042 & & & \\
\hline & $\mathrm{N} 16 \mathrm{H} \cdot \mathrm{O} 19$ & 0.051 & & & \\
\hline & $\mathrm{O} 20 \mathrm{H} \cdot \cdots \mathrm{O} 9$ & 0.119 & & & \\
\hline & $\mathrm{SH} \cdot \cdots \mathrm{O} 4$ & 0.013 & & & \\
\hline
\end{tabular}

ab, out-of-plane bend.

${ }^{b}$ Units: mdyn/Â for stretch, mdyn $\hat{A}$ for all other constants.

c Scale factors to scaled force constants for group; other constants as in pertinent reference.

d Other force constatns as in Ref. 8.

- Other force constants as in Ref. 17.

${ }^{i}$ From relationship in Ref. 16.

g Other force constants as in Ref. 12.

${ }^{\mathrm{h}}$ Other force constants as in Ref. 13.

glutamate ), ${ }^{17}$ as well as studies of others on amino acids, ${ }^{18}$ have shown that the force constants for these groups vary somewhat from one molecule to another. This is to be expected since the hydrogenbonding structures differ between molecules. It is therefore inevitable that some adjustment of these force constants will also be necessary for GSH. To avoid some arbitrariness in the choice of these force constants resulting from the redundancies around the $\mathrm{N}^{+}$and $\mathrm{C}^{-}$atoms, and to make it easier to compare the different force fields, all the force fields available for these end groups were first transformed into a common force field in which, to minimize the number of constants, the following off-diagonal force constants were set equal to zero: $\mathrm{CO}, \mathrm{C}^{\alpha} \mathrm{CO}^{\prime} ; \mathrm{NC}^{\alpha}$, $\mathrm{C}^{\alpha} \mathrm{NH} ; \mathrm{NC}^{\alpha} \mathrm{H}, \mathrm{C}^{\alpha} \mathrm{NH} ; \mathrm{HNH}, \mathrm{HNH}^{\prime} ; \mathrm{C}^{\alpha} \mathrm{NH}, \mathrm{HNH}$; $\mathrm{C}^{\alpha} \mathrm{C}, \mathrm{C}^{\alpha} \mathrm{CO}$; and $\mathrm{C}^{\alpha} \mathrm{CO}, \mathrm{C}^{\alpha} \mathrm{CO}^{\prime}$. (Conversion of the different force fields in internal coordinates to common force fields in the same local symmetry coordinates of course makes them equivalent for purposes of comparison. ${ }^{19}$ ) The Val-Gly-Gly force field ${ }^{9}$ was used as a starting point, and the force constants were then refined to confidently assignable relevant bands in the GSH spectra. These force constants are given in Table III, where they are compared with comparable values for other molecules. It can be seen that the GSH values are reasonable in relation to those from our previous studies. ${ }^{9-11,17}$

The $\gamma$-glutamyl linkage in GSH, rather than being of the typical $\alpha$-carboxyl type, is unusual and may be partly responsible, together with the close intermolecular C8 - . O20 contact, ${ }^{4}$ for the deviation from planarity of the $\mathrm{C} 8 \mathrm{~N} 10$ peptide group. The force constants associated with $\mathrm{C} 6$ and $\mathrm{C} 7$ were 
Table III Force Constants ${ }^{\mathrm{a}}$ for $\mathrm{NH}_{3}^{+}$and $\mathrm{CO}_{2}^{-}$End Groups

\begin{tabular}{|c|c|c|c|c|c|c|c|}
\hline $\begin{array}{c}\text { Force } \\
\text { Constant }^{b}\end{array}$ & $\mathrm{GSH}^{\mathrm{c}}$ & $\mathrm{VGG}^{\mathrm{d}}$ & $\mathrm{Gly}_{3}{ }^{\mathrm{e}}$ & $\mathrm{Ala}_{3}(\mathrm{ap})^{\mathbf{f}}$ & $\mathrm{Ala}_{3}(\mathrm{p})^{\mathrm{f}}$ & $\mathrm{Ca}(\mathrm{Glu})_{n}^{\mathrm{g}}$ & $\begin{array}{l}\text { Amino } \\
\text { Acids }^{h}\end{array}$ \\
\hline \multicolumn{8}{|l|}{$\mathrm{NH}_{3}^{+}$} \\
\hline $\mathrm{NH}$ & 5.230 & 5.163 & 5.350 & 5.163 & 5.163 & & 5.387 \\
\hline $\mathrm{NC}^{\alpha}$ & 4.640 & 4.832 & 4.500 & 4.523 & 4.523 & & 3.890 \\
\hline $\mathrm{NC}^{\alpha} \mathrm{t}$ & 0.366 & 0.250 & 0.200 & 0.366 & 0.366 & & 0.049 \\
\hline $\mathrm{HNH}$ & 0.541 & 0.564 & 0.583 & 0.553 & 0.554 & & 0.618 \\
\hline $\mathrm{C}^{\alpha} \mathrm{NH}$ & 0.845 & 0.814 & 0.777 & 0.836 & 0.814 & & 0.734 \\
\hline $\mathrm{NH}, \mathrm{NH}$ & 0.022 & 0.022 & 0.022 & 0.022 & 0.022 & & 0.018 \\
\hline $\mathrm{NC}^{\alpha}, \mathrm{HNH}$ & -0.461 & -0.444 & -0.444 & -0.444 & -0.444 & & -0.307 \\
\hline $\mathrm{C}^{\alpha} \mathrm{NH}, \mathrm{C}^{\alpha} \mathrm{NH}$ & -0.085 & -0.055 & -0.080 & -0.080 & -0.055 & & -0.022 \\
\hline \multicolumn{8}{|l|}{$\mathrm{CO}_{2}^{-}$} \\
\hline $\mathrm{CO}$ & 8.553 & 9.500 & 9.500 & 9.400 & 9.400 & 9.310 & 9.800 \\
\hline $\mathrm{C}^{\alpha} \mathrm{C}$ & 4.116 & 4.160 & 4.409 & 4.160 & 4.160 & 4.160 & 4.390 \\
\hline $\mathrm{OCO}$ & 1.895 & 2.000 & 2.033 & 2.100 & 2.000 & 1.933 & 1.006 \\
\hline $\mathrm{C}^{\alpha} \mathrm{CO}$ & 1.299 & 1.209 & 1.109 & 0.511 & 0.611 & 1.209 & 1.430 \\
\hline $\mathrm{CO}_{2} \mathrm{w}$ & 0.746 & 0.577 & 0.636 & 0.542 & 0.542 & 0.542 & 0.607 \\
\hline $\mathrm{CO}, \mathrm{CO}$ & 0.421 & 1.400 & 1.200 & 1.300 & 1.400 & 1.300 & 1.300 \\
\hline $\mathrm{CO}, \mathrm{C}^{\alpha} \mathrm{C}$ & 0.483 & 0.958 & 1.439 & 0.958 & 0.958 & 1.439 & 0.000 \\
\hline $\mathrm{CO}, \mathrm{OCO}$ & 0.352 & 0.374 & 0.374 & 0.509 & 0.509 & 0.374 & 2.180 \\
\hline $\mathrm{CO}, \mathrm{C}^{\alpha} \mathrm{CO}$ & 0.842 & 1.209 & 1.018 & 1.398 & 1.398 & 1.018 & 1.289 \\
\hline $\mathrm{C}^{\alpha} \mathrm{C}, \mathrm{OCO}$ & -0.945 & -0.952 & 0.519 & -0.847 & -0.847 & -0.652 & -0.392 \\
\hline $\mathrm{CO}_{2} \mathrm{w}, \mathrm{OCO}$ & 0.0 & 0.0 & 0.0 & 0.0 & 0.0 & 0.0 & 0.044 \\
\hline
\end{tabular}

${ }^{a}$ Units: mydn/ $\AA$ for stretch and stretch, stretch constants; mdøn for stretch, bend constants; mdyn $\AA$ for all others.

${ }^{\mathrm{b}} \mathbf{t}$, Torsion; w, wag.

${ }^{c}$ Glutathione, this work.

${ }^{\mathrm{d}}$ Valyl-glycyl-glycine, Ref. 9.

e Triglycine, Ref. 10.

f Trialanine, Ref. 11. ap, antiparallel chain; p, parallel chain.

s-Ca-poly (L-glutamate), Ref. 17.

h Amino acids: cysteine, serine, $\beta$-chloroalanine, Ref. 18.

therefore first transferred from $\beta$-Ca-poly (L-glutamate) ${ }^{18}$ and then some adjustments were made since the linkage of $\mathrm{C} 7$ to the peptide group makes it somewhat similar to the $\mathrm{C}^{\alpha}$ of Gly. These modified force constants are given in Table II.

In the case of the $\mathrm{CH}_{2} \mathrm{SH}$ group, we have a conformation-dependent $a b$ initio force field ${ }^{12}$ that can be transferred to GSH. As noted, this group in GSH has a conformation with $\mathrm{C}^{\alpha} \mathrm{C}^{\beta} \mathrm{SH} \sim 90^{\circ}$, and we have therefore used an ab initio force field that is the mean of the gauche $\left(60^{\circ}\right)$ and skew $\left(120^{\circ}\right)$ force constants. ${ }^{12}$ These and the empirical constants in the adjoining chain were merged as previously. ${ }^{12}$ Some small changes were then made to give better agreement with bands clearly assignable to this moiety, and the modified scale factors for these force constants are given in Table II.

The force field for the $\mathrm{CH}_{2} \mathrm{COOH}$ group was obtained from an ab initio calculation of a model system consisting of a glycine molecule, in a confor- mation similar to that found in GSH, with two water molecules hydrogen bonded to the $\mathrm{COOH}$ group. ${ }^{13}$ The motivation for this approach was to try to define the $\mathrm{C}-\mathrm{O}$ s and $\mathrm{COH}$ bend $(\mathrm{b})$ modes with greater confidence than would be possible by using empirical force fields for the acid group. These coordinates contribute to many modes, and their sensitivity to the hydrogen-bond structure makes their assignment in the spectrum far from obvious. By comparing the results for the hydrogen bonded with those for the isolated glycine,${ }^{13}$ it seems possible to arrive at reasonable initial values of the relevant force constants that can then be readily refined from the observed bands. Several aspects of this procedure are worth noting. First, the $\mathrm{COH} b$ force constant is much more sensitive to hydrogen bonding than $\mathrm{C}=\mathrm{O} \mathrm{s}$ or $\mathrm{C}-\mathrm{O}$ s: the ratio of hydrogen-bonded to isolated values is $1.84,0.91$, and 1.15 , respectively. It might be expected, therefore, that $\mathrm{COH} b$ would be quite sensitive to variations in hydrogen-bond 
structure. Second, the shifts in the $\mathrm{C}=\mathrm{O} \mathrm{s}$ and $\mathrm{C}-\mathrm{O}$ s frequencies between $\mathrm{COOH}$ and $\mathrm{COOD}$ are very sensitive to the $\mathrm{COH} b$ components of these modes, and therefore to the $\mathrm{COH} b$ force constant. From GSH to GSD, $\mathrm{C}=\mathrm{O} \mathrm{s}$ does not shift and $\mathrm{C}-\mathrm{O}$ s shifts down by $\sim 3 \mathrm{~cm}^{-1}$. This behavior can only be reproduced by a much smaller $\mathrm{COH} b$ force constant than in the glycine model, which we attribute to the very different hydrogen-bond structures: for example, besides the qualitative difference between the $\mathrm{O} 20 \mathrm{H} \cdots \mathrm{O}$ (water) and $\mathrm{O} 20 \mathrm{H} \cdots \mathrm{O} 9 \mathrm{C} 8$ bonds, the $\mathrm{C} 18 \mathrm{O} 20 \mathrm{H} \cdots$ O9 dihedral angles are very different, $-1.1^{\circ}$ vs $-120.5^{\circ}$, respectively. Finally, because of the latter angle difference, the important $\mathrm{COH}, \mathrm{OH} \cdots \mathrm{O}$ interaction force constant must change sign, since the definition of the $\mathrm{OH} \cdots \mathrm{O}$ internal coordinate involves a sign reversal between $0^{\circ}$ and $180^{\circ}$. The scale factors for these modified force constants are given in Table II.

Transition dipole coupling, ${ }^{20,21}$ in the dipole derivative coupling (DDC) formalism, ${ }^{9}$ was computed for the amide I and amide II modes. Since the respective force constants for the two peptide groups are different ( because of the different hydrogen bond structures ), the intramolecular modes are relatively pure and this interaction effect is very small. Because of the large distances between equivalent groups in the unit cell, the calculated shifts for different symmetry species are also very small.

\section{RESULTS AND DISCUSSION}

The internal and local symmetry coordinates of the hydrogen-bonded GSH are given in Tables IV and $\mathrm{V}$, respectively. The observed ir and Raman bands and the calculated normal modes and potential energy distributions (PED) of GSH are given in Table VI, and the comparable quantities for GSD are given in Table VII. We present results only in the region of observation, above about $300 \mathrm{~cm}^{-1}$. Below this region, the modes involve low frequency skeletal deformations and intermolecular hydrogen-bond motions. Since these force constants are at best uncertain, and nonbonded interactions between molecules have not been included in the calculation, it is not fruitful at this stage to place much confidence in the details of this low frequency region.

Most of the assignments, which are based on the deuteration results and the normal mode calculations, are generally quite satisfactory. Spectra of other isotopic derivatives would obviously be valuable in confirming those that are less certain.

\section{XH Stretch Region}

A detailed assignment of the NH s modes is complicated by the Fermi resonances in this region ${ }^{22}$ and the overlap with the $\mathrm{OH} s$ and $\mathrm{NH}_{3}^{+} \mathrm{s}$ modes. Nevertheless, reasonable assignments can be suggested. For the latter group, consistent with results on other tripeptides, ${ }^{9-11}$ we assign $\mathrm{NH}_{3}^{+}$symmetric stretch (ss), calculated at $3027 \mathrm{~cm}^{-1}$, to the observed band at $3031 \mathrm{~cm}^{-1}$, probably overlapped with amide $\mathrm{B}$ ( found at $3058-3080 \mathrm{~cm}^{-1}$ in polypeptides ${ }^{22}$ ); and we assign $\mathrm{NH}_{3}^{+}$antisymmetric stretch (as), calculated at 3122 and $3111 \mathrm{~cm}^{-1}$, to the observed band at $3130 \mathrm{~cm}^{-1}$. If the $3251 \mathrm{~cm}^{-1}$ band is assigned to $\mathrm{NH}_{3}^{+}$as, then there are no reasonable assignments for the 2396 and $2346 \mathrm{~cm}^{-1}$ bands of GSD. With our proposed assignments, the observed GSD bands at 2346 and $2189 \mathrm{~cm}^{-1}$ are accounted for (making allowances for differences in anharmonicities between $\mathrm{NH}$ and ND modes) by calculated $\mathrm{NH}_{3}^{+}$as and $\mathrm{ND}_{3}^{+}$ss modes at 2316,2310 , and $2174 \mathrm{~cm}^{-1}$, respectively. (We attribute the relatively strong 2252 $\mathrm{cm}^{-1}$ band, as well as comparable bands at 2061 and $2018 \mathrm{~cm}^{-1}$, to combinations and/or overtones.) The $\mathrm{N} 16 \mathrm{H}$ s and $\mathrm{N} 10 \mathrm{H}$ s modes are then naturally assigned to calculated (and observed) bands at 3262 (3251) and $3344(3348) \mathrm{cm}^{-1}$, respectively. Their shift to 2403 (2396) and $2462(2495) \mathrm{cm}^{-1}$, respectively, in GSD supports this assignment.

Since the $\mathrm{N} 16 \mathrm{H} \cdots \mathrm{O}$ is the stronger of the two peptide hydrogen bonds, the $\mathrm{N} 16 \mathrm{H}$ s band would be expected to be the more intense. ${ }^{23}$ This is not the case, suggesting that the observed $3348 \mathrm{~cm}^{-1}$ band may contain another contribution. (Part of its intensity may be due to what seems to be a broad underlying band centered near $3425 \mathrm{~cm}^{-1}$ - compare the GSD spectrum-and perhaps due to water on the $\mathrm{KBr}$ pellet.) We assign the $\mathrm{OH}$ s mode also to this band for two main reasons: in the glycine$\left(\mathrm{H}_{2} \mathrm{O}\right)_{2}$ model $^{13}$ this frequency occurs near 3340 $\mathrm{cm}^{-1}$, and in GSD the OD s mode separates from $\mathrm{N} 10 \mathrm{D} \mathrm{s}$, being predicted at $2443 \mathrm{~cm}^{-1}$ with a band being observed at $2434 \mathrm{~cm}^{-1}$.

Seven observed ir and Raman bands in the 3000 $2850 \mathrm{~cm}^{-1}$ region that remain unchanged from GSH to GSD can be assigned to $\mathrm{CH}_{2}$ and $\mathrm{CH}$ stretch modes. (The $2834 \mathrm{~cm}^{-1}$ band of GSH is much weaker in GSD, and is probably a combination band.) Fermi resonances are also involved in this region, ${ }^{24}$ but preliminary reasonable assignments seem possible. The $\mathrm{C}_{12} \mathrm{H}_{2}$ as mode at $2979(2970) \mathrm{cm}^{-1}$ and the $\mathrm{C}_{12} \mathrm{H}_{2}$ ss mode at $2937(2935) \mathrm{cm}^{-1}$ are consistent with similar bands found in ethanethiol at 2980 and 


\begin{tabular}{|c|c|c|}
\hline \multicolumn{3}{|c|}{ Bonds } \\
\hline $\mathrm{R} 1=\Delta r(\mathrm{~N} 1-\mathrm{C} 2)$ & $\mathrm{R} 16=\Delta r(\mathrm{C} 8-\mathrm{O} 9)$ & $\mathrm{R} 31=\Delta r(\mathrm{C} 12-\mathrm{H} 1)$ \\
\hline $\mathrm{R} 2=\Delta r(\mathrm{~N} 10-\mathrm{C} 11)$ & $\mathrm{R} 17=\Delta r(\mathrm{C} 14-\mathrm{O} 15)$ & $\mathrm{R} 32=\Delta r(\mathrm{C} 12-\mathrm{H} 2)$ \\
\hline $\mathrm{R} 3=\Delta r(\mathrm{~N} 16-\mathrm{C} 17)$ & $\mathrm{R} 18=\Delta r(\mathrm{C} 18-\mathrm{O} 19)$ & $\mathrm{R} 33=\Delta r(\mathrm{C} 12-\mathrm{S} 13)$ \\
\hline $\mathrm{R4}=\Delta r(\mathrm{C} 2-\mathrm{C} 3)$ & $\mathrm{R} 19=\Delta r(\mathrm{C} 2-\mathrm{C} 6)$ & $\mathrm{R} 34=\Delta r(\mathrm{~S} 13-\mathrm{H})$ \\
\hline $\mathrm{R} 5=\Delta r(\mathrm{C} 11-\mathrm{C} 14)$ & $\mathrm{R} 20=\Delta r(\mathrm{C} 6-\mathrm{C} 7)$ & $\mathrm{R} 35=\Delta r(\mathrm{C} 18-\mathrm{O} 20)$ \\
\hline $\mathrm{R} 6=\Delta r(\mathrm{C} 17-\mathrm{C} 18)$ & $\mathrm{R} 21=\Delta r(\mathrm{C} 11-\mathrm{C} 12)$ & $\mathrm{R} 36=\Delta r(\mathrm{O} 20-\mathrm{H})$ \\
\hline $\mathrm{R} 7=\Delta r(\mathrm{C} 8-\mathrm{N} 10)$ & $\mathrm{R} 22=\Delta r(\mathrm{C} 7-\mathrm{C} 8)$ & $\mathrm{R} 37=\Delta r(\mathrm{O} 4 \cdots \mathrm{H} 1[\mathrm{~N} 1])$ \\
\hline $\mathrm{R} 8=\Delta r(\mathrm{C} 14-\mathrm{N} 16)$ & $\mathrm{R} 23=\Delta r(\mathrm{C} 2-\mathrm{H})$ & $\mathrm{R} 38=\Delta r(\mathrm{O} 4 \cdots \mathrm{H}[\mathrm{S}])$ \\
\hline $\mathrm{R} 9=\Delta r(\mathrm{~N} 1-\mathrm{H} 1)$ & $\mathrm{R} 24=\Delta r(\mathrm{C} 11-\mathrm{H})$ & $\mathrm{R} 39=\Delta r(\mathrm{O} 5 \cdots \mathrm{H} 3[\mathrm{~N} 1])$ \\
\hline $\mathrm{R} 10=\Delta r(\mathrm{~N} 1-\mathrm{H} 2)$ & $\mathrm{R} 25=\Delta r(\mathrm{C} 17-\mathrm{H} 1)$ & $\mathrm{R} 40=\Delta r(\mathrm{O} 5 \cdots \mathrm{H}[\mathrm{N} 10])$ \\
\hline $\mathrm{R} 11=\Delta r(\mathrm{~N} 1-\mathrm{H} 3)$ & $\mathrm{R} 26=\Delta r(\mathrm{C} 17-\mathrm{H} 2)$ & $\mathrm{R} 41=\Delta r(\mathrm{O} 9 \cdots \mathrm{H})$ \\
\hline $\mathrm{R} 12=\Delta r(\mathrm{~N} 10-\mathrm{H})$ & $\mathrm{R} 27=\Delta r(\mathrm{C} 6-\mathrm{H} 1)$ & $\mathrm{R} 42=\Delta r(\mathrm{O} 15 \cdots \mathrm{H})$ \\
\hline $\mathrm{R} 13=\Delta r(\mathrm{~N} 16-\mathrm{H})$ & $\mathrm{R} 28=\Delta r(\mathrm{C} 6-\mathrm{H} 2)$ & $\mathrm{R} 43=\Delta r(\mathrm{O} 19 \cdot \cdots \mathrm{H})$ \\
\hline $\mathrm{R} 14=\Delta r(\mathrm{C} 3-\mathrm{O} 4)$ & $\mathrm{R} 29=\Delta r(\mathrm{C} 7-\mathrm{H} 1)$ & \\
\hline $\mathrm{R} 15=\Delta r(\mathrm{C} 3-\mathrm{O} 5)$ & $\mathrm{R} 30=\Delta r(\mathrm{C} 7-\mathrm{H} 2)$ & \\
\hline \multicolumn{3}{|c|}{ Angles } \\
\hline $\mathrm{R} 44=\Delta \theta(\mathrm{H} 1-\mathrm{N} 1-\mathrm{H} 2)$ & $\mathrm{R} 70=\Delta \theta(\mathrm{C} 7-\mathrm{C} 6-\mathrm{H} \mathbf{1})$ & $\mathrm{R} 96=\Delta \theta(\mathrm{C} 12-\mathrm{S}-\mathrm{H})$ \\
\hline $\mathrm{R} 45=\Delta \theta(\mathrm{H} 2-\mathrm{N} 1-\mathrm{H} 3)$ & $\mathrm{R} 71=\Delta \theta(\mathrm{C} 6-\mathrm{C} 7-\mathrm{C} 8)$ & $\mathrm{R} 97=\Delta \theta(\mathrm{C} 11-\mathrm{C} 14-\mathrm{N} 16)$ \\
\hline $\mathrm{R} 46=\Delta \theta(\mathrm{H} 1-\mathrm{N} 1-\mathrm{H} 3)$ & $\mathrm{R} 72=\Delta \theta(\mathrm{C} 8-\mathrm{C} 7-\mathrm{H} 2)$ & $\mathrm{R} 98=\Delta \theta(\mathrm{N} 16-\mathrm{C} 14-\mathrm{O} 15)$ \\
\hline $\mathrm{R} 47=\Delta \theta(\mathrm{C} 2-\mathrm{N} 1-\mathrm{H} 1)$ & $\mathrm{R} 73=\Delta \theta(\mathrm{H} 1-\mathrm{C} 7-\mathrm{H} 2)$ & $\mathrm{R} 99=\Delta \theta(\mathrm{C} 11-\mathrm{C} 14-\mathrm{O} 15)$ \\
\hline $\mathrm{R} 48=\Delta \theta(\mathrm{C} 2-\mathrm{N} 1-\mathrm{H} 2)$ & $\mathrm{R} 74=\Delta \theta(\mathrm{C} 6-\mathrm{C} 7-\mathrm{H} 1)$ & $\mathrm{R} 100=\Delta \theta(\mathrm{C} 14-\mathrm{O} 15 \cdots \mathrm{H})$ \\
\hline $\mathrm{R} 49=\Delta \theta(\mathrm{C} 2-\mathrm{N} 1-\mathrm{H} 3)$ & $\mathrm{R} 75=\Delta \theta(\mathrm{C} 6-\mathrm{C} 7-\mathrm{H} 2)$ & $\mathrm{R} 101=\Delta \theta(\mathrm{C} 14-\mathrm{N} 16-\mathrm{C} 17)$ \\
\hline $\mathrm{R} 50=\Delta \theta(\mathrm{N} 1-\mathrm{C} 2-\mathrm{C} 3)$ & $\mathrm{R} 76=\Delta \theta(\mathrm{C} 8-\mathrm{C} 7-\mathrm{H} 1)$ & $\mathrm{R} 102=\Delta \theta(\mathrm{C} 14-\mathrm{N} 16-\mathrm{H})$ \\
\hline $\mathrm{R} 51=\Delta \theta(\mathrm{N} 1-\mathrm{C} 2-\mathrm{C} 6)$ & $\mathrm{R} 77=\Delta \theta(\mathrm{C} 7-\mathrm{C} 8-\mathrm{N} 10)$ & $\mathrm{R} 103=\Delta \theta(\mathrm{C} 17-\mathrm{N} 16-\mathrm{H})$ \\
\hline $\mathrm{R} 52=\Delta \theta(\mathrm{C} 3-\mathrm{C} 2-\mathrm{C} 6)$ & $\mathrm{R} 78=\Delta \theta(\mathrm{N} 10-\mathrm{C} 8-\mathrm{O} 9)$ & $\mathrm{R} 104=\Delta \theta(\mathrm{N} 16-\mathrm{C} 17-\mathrm{C} 18)$ \\
\hline $\mathrm{R} 53=\Delta \theta(\mathrm{H}-\mathrm{C} 2-\mathrm{C} 6)$ & $\mathrm{R} 79=\Delta \theta(\mathrm{C} 7-\mathrm{C} 8-\mathrm{O} 9)$ & $\mathrm{R} 105=\Delta \theta(\mathrm{C} 18-\mathrm{C} 17-\mathrm{H} 2)$ \\
\hline $\mathrm{R} 54=\Delta \theta(\mathrm{N} 1-\mathrm{C} 2-\mathrm{H})$ & $\mathrm{R} 80=\Delta \theta(\mathrm{C} 8-\mathrm{O} 9 \cdots \mathrm{H})$ & $\mathrm{R} 106=\Delta \theta(\mathrm{H} 1-\mathrm{C} 17-\mathrm{H} 2)$ \\
\hline $\mathrm{R} 55=\Delta \theta(\mathrm{H}-\mathrm{C} 2-\mathrm{C} 3)$ & $\mathrm{R} 81=\Delta \theta(\mathrm{C} 8-\mathrm{N} 10-\mathrm{C} 11)$ & $\mathrm{R} 107=\Delta \theta(\mathrm{N} 16-\mathrm{C} 17-\mathrm{H} 1)$ \\
\hline $\mathrm{R} 56=\Delta \theta(\mathrm{O} 4-\mathrm{C} 3-\mathrm{O} 5)$ & $\mathrm{R} 82=\Delta \theta(\mathrm{C} 8-\mathrm{N} 10-\mathrm{H})$ & $\mathrm{R} 108=\Delta \theta(\mathrm{N} 16-\mathrm{C} 17-\mathrm{H} 2)$ \\
\hline $\mathrm{R} 57=\Delta \theta(\mathrm{C} 2-\mathrm{C} 3-\mathrm{O} 4)$ & $\mathbf{R} 83=\Delta \theta(\mathrm{C} 11-\mathrm{N} 10-\mathrm{H})$ & $\mathbf{R} 109=\Delta \theta(\mathrm{C} 18-\mathrm{C} 17-\mathrm{H} 1)$ \\
\hline
\end{tabular}

$2931 \mathrm{~cm}^{-1}$, respectively. ${ }^{12}$ Expected $\mathrm{C}^{\alpha} \mathrm{H}^{\alpha}$ modes are well predicted near the observed band at $2863 \mathrm{~cm}^{-1}$. The $\mathrm{C}_{17} \mathrm{H}_{2}$ modes correspond to similar bands found for such a terminal group in other tripeptides, ${ }^{9,10}$ and the $\mathrm{C}_{6} \mathrm{H}_{2}, \mathrm{C}_{7} \mathrm{H}_{2}$ modes are also fairly well accounted for. Secure assignments in this region will clearly be possible only when $\mathrm{CD}_{2}$-substituted molecules can be studied.

The SH s mode is confidently assignable to the observed $2524 \mathrm{~cm}^{-1}$ band of GSH. However, its frequency is much lower than the $2560-2565 \mathrm{~cm}^{-1}$ found for ethanethiol in the condensed state. ${ }^{12}$ Part of this difference may be due to differences in the nature of the hydrogen bonding, since conformational differences do not significantly affect this mode. ${ }^{12}$ Another possibility is a Fermi resonance interaction with a combination band (for example, a possibility involving this group is $1559+1015$ $=2574$ ), giving rise to the observed 2625 and 2524 $\mathrm{cm}^{-1}$ bands. The shift to $1837 \mathrm{~cm}^{-1}$ in GSD confirms this general assignment, although this band may also be involved in Fermi resonance with the $1865 \mathrm{~cm}^{-1}$ band.

\section{Amides I and II Region}

This region, from $1720-1490 \mathrm{~cm}^{-1}$, can be very well assigned, despite the overlap from bands due to the $\mathrm{NH}_{3}^{+}$and $\mathrm{CO}_{2}^{-}$groups.

The ir band at $1713 \mathrm{~cm}^{-1}$ is clearly due to $\mathrm{CO} 19$ $\mathrm{s}$, being calculated at $1711 \mathrm{~cm}^{-1}$ with the comparable force constant transferred without change from the ab initio glycine model force field. ${ }^{13}$ As noted above, the absence of a shift in GSD is due to a very small contribution of $\mathrm{COH} b$ to this mode, which helps to determine the latter force constant.

The two amide I modes (mainly $\mathrm{C}=\mathrm{O}$ s with some $\mathrm{CN} \mathrm{s}$ ) are well predicted, based on their $\mathrm{C}=\mathrm{O}$ bond lengths and respective force constants (the CO19 bond length of $1.195 \AA$ and its higher frequency fits in with this general relationship). The unperturbed modes were calculated at $1660.1 \mathrm{~cm}^{-1}$ 


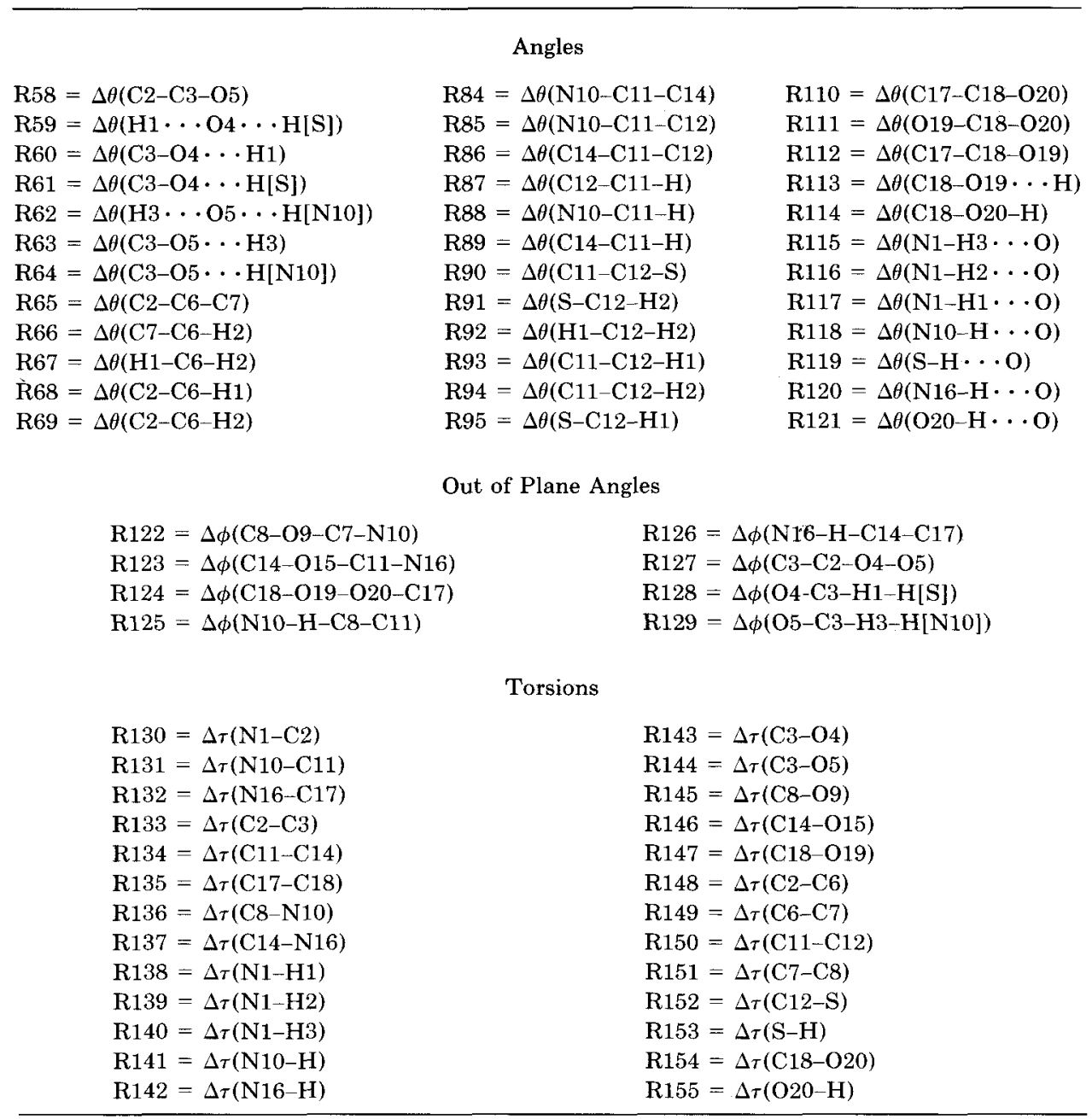

for amide I of C8N, with DDC shifts of 0.5 (A) , -4.2 $\left(\mathrm{B}_{1}\right), 0.5\left(\mathrm{~B}_{2}\right)$, and $1.7\left(\mathrm{~B}_{3}\right) \mathrm{cm}^{-1}$, and at 1627.2 $\mathrm{cm}^{-1}$ for amide $I$ of $\mathrm{C} 14 \mathrm{~N}$, with DDC shifts of 0.6 (A), $2.1\left(\mathrm{~B}_{1}\right), 1.9\left(\mathrm{~B}_{2}\right)$, and $1.2\left(\mathrm{~B}_{3}\right) \mathrm{cm}^{-1}$. The small shifts are of course due to the very different unperturbed frequencies, and consequent minimal mixing of the two modes in the eigenvectors of one molecule, and the relatively large separation of equivalent groups between the four molecules in the unit cell. The observed downshifts on deuteration, about 6 and $10 \mathrm{~cm}^{-1}$, respectively, are moderately well reproduced, viz., 5 and $6 \mathrm{~cm}^{-1}$, respectively.

The $\mathrm{NH}_{3}^{+}$ab mode can be assigned to the 1615 $\mathrm{cm}^{-1}$ band, which disappears on deuteration, and the similar behavior of the $1492 \mathrm{~cm}^{-1}$ band suggests its assignment to $\mathrm{NH}_{3}^{+}$sb. Both of these are well reproduced by the calculation, 1618 and $1492 \mathrm{~cm}^{-1}$, respectively. The other component of $\mathrm{NH}_{3}^{+}$ab, pre- dicted at $1595 \mathrm{~cm}^{-1}$, may be within the $1600 \mathrm{~cm}^{-1}$ band, which, because it is not much affected by deuteration, we assign to $\mathrm{CO}_{2}^{-}$as. $\mathrm{ND}_{3}^{+}$as modes are predicted at 1155 and $1116 \mathrm{~cm}^{-1}$, with the new 1117 $\mathrm{cm}^{-1}$ band being assignable to the latter. The new bands at 1098 and $1063 \mathrm{~cm}^{-1}$ in GSD can be assigned to $\mathrm{ND}_{3}^{+} \mathrm{sb}$, predicted at 1090 and $1066 \mathrm{~cm}^{-1}$, respectively.

The amide II modes ( $\mathrm{NH}$ ib $+\mathrm{CN}$ s) are well assigned to the two bands at 1559 and $1537 \mathrm{~cm}^{-1}$, with the higher frequency band associated with the more strongly hydrogen bonded group, $\mathrm{N} 16 \mathrm{H}$. These modes are predicted to shift on deuteration to 1492 $(\mathrm{C} 14 \mathrm{~N} \mathrm{~s})$ and 1471 (mostly $\mathrm{C} \mathrm{H}_{2}$ b but with a significant $\mathrm{C} 8 \mathrm{~N}$ s component) $\mathrm{cm}^{-1}$, and new bands are observed in GSD at 1486 and $1465 \mathrm{~cm}^{-1}$. The DDC contributions to amide II are very small $(<0.5$ $\mathrm{cm}^{-1}$ ). 
Table V Local Symmetry Coordinates of GSH

\begin{tabular}{|c|c|c|c|}
\hline Symmetry Coordinate & Description $^{a}$ & Symmetry Coordinate & Description $^{a}$ \\
\hline \multicolumn{4}{|c|}{ Stretches } \\
\hline $\mathbf{S} 1=\mathbf{R} 1$ & N1C s & $\mathrm{S} 23=\mathrm{R} 23$ & $\mathrm{C} 2 \mathrm{H} \mathrm{s}$ \\
\hline $\mathrm{S} 2=\mathrm{R} 2$ & NC11 s & $\mathrm{S} 24=\mathrm{R} 24$ & $\mathrm{C} 11 \mathrm{H} \mathrm{s}$ \\
\hline $\mathrm{S} 3=\mathrm{R} 3$ & $\mathrm{NC17} \mathrm{s}$ & $\mathrm{S} 25=\mathrm{R} 25+\mathrm{R} 26$ & $\mathrm{C}_{17 \mathrm{H}_{2}}$ ss \\
\hline $\mathrm{S} 4=\mathrm{R} 4$ & $\mathrm{CC} 3 \mathrm{~s}$ & $\mathrm{~S} 26=\mathrm{R} 25-\mathrm{R} 26$ & $\mathrm{C} 17 \mathrm{H}_{2}$ as \\
\hline $\mathbf{S} 5=\mathbf{R} 5$ & CC14 s & $\mathrm{S} 27=\mathrm{R} 27+\mathrm{R} 28$ & $\mathrm{C}_{6} \mathrm{H}_{2}$ ss \\
\hline $\mathrm{S} 6=\mathrm{R} 6$ & $\mathrm{C} 17 \mathrm{C} \mathrm{s}$ & $\mathrm{S} 28=\mathrm{R} 27-\mathrm{R} 28$ & $\mathrm{C}_{6} \mathrm{H}_{2}$ as \\
\hline $\mathrm{S} 7=\mathrm{R} 7$ & $\mathrm{C} 8 \mathrm{~N} \mathrm{~s}$ & $\mathrm{~S} 29=\mathrm{R} 29+\mathrm{R} 30$ & $\mathrm{C} 7 \mathrm{H}_{2} \mathrm{ss}$ \\
\hline $\mathbf{S} 8=\mathbf{R} 8$ & $\mathrm{C} 14 \mathrm{~N}$ s & $\mathrm{S} 30=\mathrm{R} 29-\mathrm{R} 30$ & $\mathrm{C} 7 \mathrm{H}_{2}$ as \\
\hline $\mathrm{S} 9=\mathrm{R} 9+\mathrm{R} 10+\mathrm{R} 11$ & $\mathrm{NH}_{3} \mathrm{ss}$ & $\mathrm{S} 31=\mathrm{R} 31+\mathrm{R} 32$ & $\mathrm{C}_{12} \mathrm{H}_{2} \mathrm{ss}$ \\
\hline $\mathrm{S} 10=\mathrm{R} 9-\mathrm{R} 10$ & $\mathrm{NH}_{3}$ as 1 & $\mathrm{~S} 32=\mathrm{R} 31-\mathrm{R} 32$ & $\mathrm{C}_{12} \mathrm{H}_{2}$ as \\
\hline $\mathrm{S} 11=2 \mathrm{R} 11-\mathrm{R} 9-\mathrm{R} 10$ & $\mathrm{NH}_{3}$ as2 & $\mathrm{S} 33=\mathrm{R} 33$ & $\mathrm{CS} \mathrm{s}$ \\
\hline $\mathrm{S} 12=\mathbf{R} 12$ & $\mathrm{~N} 10 \mathrm{H}$ s & $\mathrm{S} 34=\mathrm{R} 34$ & $\mathrm{SH} \mathrm{s}$ \\
\hline $\mathbf{S} 13=\mathbf{R} 13$ & $\mathrm{~N} 16 \mathrm{H} \mathrm{s}$ & $\mathrm{S} 35=\mathrm{R} 35$ & $\mathrm{CO} 20 \mathrm{~s}$ \\
\hline $\mathbf{S} 14=\mathbf{R} 14+\mathbf{R} 15$ & $\mathrm{CO}_{2}$ ss & $\mathrm{S} 36=\mathrm{R} 36$ & $\mathrm{OH} \mathrm{s}$ \\
\hline $\mathrm{S} 15=\mathrm{R} 14-\mathrm{R} 15$ & $\mathrm{CO}_{2}$ as & $\mathbf{S} 37=\mathrm{R} 37$ & $\mathrm{O} 4 \cdots \mathrm{H} 1[\mathrm{~N} 1] \mathrm{s}$ \\
\hline $\mathrm{S} 16=\mathrm{R} 16$ & $\mathrm{C} 8 \mathrm{O} \mathrm{s}_{\mathrm{s}}$ & $\mathrm{S} 38=\mathrm{R} 38$ & $\mathrm{O} 4 \cdots \mathrm{H}[\mathrm{S}] \mathrm{s}$ \\
\hline $\mathrm{S} 17=\mathrm{R} 17$ & $\mathrm{C} 14 \mathrm{O} \mathrm{s}$ & $\mathrm{S} 39=\mathrm{R} 39$ & $\mathrm{O} 5 \cdots \mathrm{H} 3[\mathrm{~N} 1] \mathrm{s}$ \\
\hline $\mathrm{S} 18=\mathrm{R} 18$ & CO19s & $\mathrm{S} 40=\mathrm{R} 40$ & $\mathrm{O} 5 \cdots \mathrm{H}[\mathrm{N} 10] \mathrm{s}$ \\
\hline $\mathrm{S} 19=\mathrm{R} 19$ & $\mathrm{C} 2 \mathrm{C} 6 \mathrm{~s}$ & $\mathrm{~S} 41=\mathrm{R} 41$ & $\mathrm{O} 9 \cdot \mathrm{H} \mathrm{s}$ \\
\hline $\mathrm{S} 20=\mathrm{R} 20$ & $\mathrm{C} 6 \mathrm{C} 7 \mathrm{~s}$ & $\mathrm{~S} 42=\mathrm{R} 42$ & $\mathrm{O} 15 \cdots \mathrm{H} \mathrm{s}$ \\
\hline $\mathrm{S} 21=\mathrm{R} 21$ & $\mathrm{CC} 12 \mathrm{~s}$ & $\mathrm{~S} 43=\mathrm{R} 43$ & $\mathrm{O} 19 \cdots \mathrm{H} \mathrm{s}$ \\
\hline \multirow[t]{2}{*}{$\mathrm{S} 22=\mathrm{R} 22$} & $\mathrm{CC} 8 \mathrm{~s}$ & & \\
\hline & \multicolumn{3}{|l|}{ Deformations } \\
\hline $\mathrm{S} 44=\mathrm{R} 44+\mathrm{R} 45+\mathrm{R} 46-\mathrm{R} 47-\mathrm{R} 48-\mathrm{R} 49$ & $\mathrm{NH}_{3} \mathbf{s b}$ & $\mathrm{S} 76=2 \mathrm{R} 84-\mathrm{R} 85-\mathrm{R} 86$ & $\mathrm{C} 12 \mathrm{~b} 1$ \\
\hline $\mathrm{S} 45=2 \mathrm{R} 44-\mathrm{R} 45-\mathrm{R} 46$ & $\mathrm{NH}_{3} \mathrm{ab} 1$ & $\mathrm{~S} 77=\mathrm{R} 85-\mathrm{R} 86$ & $\mathrm{C} 12 \mathrm{~b} 2$ \\
\hline $\mathrm{S} 46=\mathrm{R} 45-\mathrm{R} 46$ & $\mathrm{NH}_{3} \mathrm{ab} 2$ & $\mathrm{~S} 78=2 \mathrm{R} 87-\mathrm{R} 88-\mathrm{R} 89$ & $\mathrm{H}^{\alpha}[\mathrm{C} 11] \mathrm{b} 1$ \\
\hline $\mathrm{S} 47=2 \mathrm{R} 47-\mathrm{R} 48-\mathrm{R} 49$ & $\mathrm{NH}_{3} \mathbf{r} 1$ & $\mathrm{~S} 79=\mathrm{R} 88-\mathrm{R} 89$ & $\mathrm{H}^{\alpha}[\mathrm{C} 11] \mathrm{b} 2$ \\
\hline $\mathrm{S} 48=\mathrm{R} 48-\mathrm{R} 49$ & $\mathrm{NH}_{3} \mathbf{r} 2$ & $\mathrm{~S} 80=$ 5R90-R91-R92-R93-R94-R95 & $\operatorname{CCS} \mathrm{d}$ \\
\hline $\mathrm{S} 49=\mathrm{R} 50+\mathrm{R} 51+\mathrm{R} 52-\mathrm{R} 53-\mathrm{R} 54-\mathrm{R} 55$ & NCC3 d & $\mathrm{S} 81=4 \mathrm{R} 92-\mathrm{R} 91-\mathrm{R} 93-\mathrm{R} 94-\mathrm{R} 95$ & $\mathrm{C} 12 \mathbf{H}_{2} \mathbf{b}$ \\
\hline $\mathrm{S} 50=2 \mathrm{R} 50-\mathrm{R} 51-\mathrm{R} 52$ & $\mathrm{C} 3 \mathrm{~b} 1$ & $\mathrm{~S} 82=\mathrm{R} 91-\mathrm{R} 93-\mathrm{R} 94+\mathrm{R} 95$ & $\mathrm{C}_{12} \mathrm{H}_{2} \mathrm{w}$ \\
\hline $\mathrm{S} 51=\mathrm{R} 51-\mathrm{R} 52$ & $\mathrm{C} 3 \mathrm{~b} 2$ & $\mathrm{~S} 83=-\mathrm{R} 91+\mathrm{R} 93-\mathrm{R} 94+\mathrm{R} 95$ & $\mathrm{C}_{12} \mathrm{H}_{2} \mathrm{r}$ \\
\hline $\mathrm{S} 52=2 \mathrm{R} 53-\mathrm{R} 54-\mathrm{R} 55$ & $\mathbf{H}^{\alpha}[\mathrm{C} 2] \mathrm{b} 1$ & $\mathrm{~S} 84=\mathrm{R} 91+\mathrm{R} 93-\mathrm{R} 94-\mathrm{R} 95$ & $\mathrm{C} 12 \mathrm{H}_{2}$ tw \\
\hline $\mathrm{S} 53=\mathrm{R} 54-\mathrm{R} 55$ & $\mathrm{H}^{\alpha}[\mathrm{C} 2] \mathrm{b} 2$ & $\mathrm{~S} 85=\mathrm{R} 96$ & $\mathrm{CSH} \mathbf{b}$ \\
\hline $\mathrm{S} 54=2 \mathrm{R} 56-\mathrm{R} 57-\mathrm{R} 58$ & $\mathrm{CO}_{2} \mathrm{~b}$ & $\mathrm{~S} 86=2 \mathrm{R} 97-\mathrm{R} 98-\mathrm{R} 99$ & CC14N d \\
\hline $\mathrm{S} 55=\mathrm{R} 57-\mathrm{R} 58$ & $\mathrm{CO}_{2} \mathbf{r}$ & $\mathrm{S} 87=\mathrm{R} 98-\mathrm{R} 99$ & $\mathrm{C} 140 \mathrm{ib}$ \\
\hline $\mathrm{S} 56=2 \mathrm{R} 59-\mathrm{R} 60-\mathrm{R} 61$ & $\mathrm{O} 4 \cdots \mathrm{H}_{2} \mathbf{b}$ & $\mathbf{S} 88=\mathbf{R} 100$ & $\mathrm{C} 140 \cdots \mathrm{H} \mathrm{b}$ \\
\hline $\mathrm{S} 57=\mathrm{R} 60-\mathrm{R} 61$ & $\mathrm{O} 4 \cdots \mathrm{H}_{2} \mathrm{r}$ & $\mathrm{S} 89=2 \mathrm{R} 101-\mathrm{R} 102-\mathrm{R} 103$ & CN16C d \\
\hline $\mathrm{S} 58=2 \mathrm{R} 62-\mathrm{R} 63-\mathrm{R} 64$ & $\mathrm{O} 5 \cdots \mathrm{H}_{2} \mathbf{b}$ & $\mathrm{S} 90=\mathrm{R} 102-\mathrm{R} 103$ & $\mathrm{~N} 16 \mathrm{H}$ ib \\
\hline $\mathrm{S} 59=\mathrm{R} 63-\mathrm{R} 64$ & $\mathrm{O} 5 \cdots \mathrm{H}_{2} \mathrm{r}$ & $\mathrm{S} 91=5 \mathrm{R} 104-\mathrm{R} 105-\mathrm{R} 106-\mathrm{R} 107-\mathrm{R} 108-\mathrm{R} 109$ & $\mathrm{NC} 17 \mathrm{C} \mathrm{d}$ \\
\hline $\mathrm{S} 60=5 \mathrm{R} 65-\mathrm{R} 66-\mathrm{R} 67-\mathrm{R} 68-\mathrm{R} 69-\mathrm{R} 70$ & $\mathrm{CC} 6 \mathrm{C} \mathrm{d}$ & $\mathrm{S} 92=4 \mathrm{R} 106-\mathrm{R} 105-\mathrm{R} 107-\mathrm{R} 108-\mathrm{R} 109$ & $\mathrm{C} 17 \mathrm{H}_{2} \mathbf{b}$ \\
\hline $\mathrm{S} 61=4 \mathrm{R} 67-\mathrm{R} 66-\mathrm{R} 68-\mathrm{R} 69-\mathrm{R} 70$ & $\mathrm{C}_{6} \mathrm{H}_{2} \mathrm{~b}$ & $\mathrm{~S} 93=\mathrm{R} 105-\mathrm{R} 107-\mathrm{R} 108+\mathrm{R} 109$ & $\mathrm{C}_{17} \mathrm{H}_{2} \mathrm{w}$ \\
\hline $\mathrm{S} 62=\mathrm{R} 66-\mathrm{R} 68-\mathrm{R} 69+\mathrm{R} 70$ & $\mathrm{C} 6 \mathrm{H}_{2} \mathrm{w}$ & $\mathrm{S} 94=-\mathrm{R} 105+\mathrm{R} 107-\mathrm{R} 108+\mathrm{R} 109$ & $\mathrm{C} 17 \mathrm{H}_{2} \mathrm{r}$ \\
\hline $\mathrm{S} 63=-\mathrm{R} 66+\mathrm{R} 68-\mathrm{R} 69+\mathrm{R} 70$ & $\mathrm{C}_{6} \mathrm{H}_{2} \mathrm{r}$ & $\mathrm{S} 95=\mathrm{R} 105+\mathrm{R} 107-\mathrm{R} 108-\mathrm{R} 109$ & $\mathrm{C}_{17 \mathrm{H}_{2}}$ tw \\
\hline
\end{tabular}

\section{$1500-1100 \mathrm{~cm}^{-1}$ Region}

The region from 1500 to about $1100 \mathrm{~cm}^{-1}$ usually encompasses a number of $\mathrm{CH}_{2}$ and $\mathrm{CH}$ as well as $\mathrm{NH}$ deformation modes, the $\mathrm{CO}_{2}^{-}$ss mode, and the so-called amide III mode. In the case of GSH we also have to include the $\mathrm{C}-\mathrm{O}$ s and $\mathrm{COH} b$ modes. The amide III mode has classically been considered to be a localized $\mathrm{NH}$ ib $+\mathrm{CN}$ s counterpart to amide

II, ${ }^{25}$ but as has been pointed out, ${ }^{8}$ this is a much oversimplified description. Even in polypeptides $\mathrm{CN}$ $s$ may not be a significant contributor, and in small peptides ${ }^{9-11}$ it is often absent, with $\mathrm{NH}$ ib contributing to many modes in this region. This also seems to be the case for GSH.

The observed bands at 1453 and $1442 \mathrm{~cm}^{-1}$ in GSH, which shift to 1445 and $1439 \mathrm{~cm}^{-1}$ GSD, are clearly assignable to $\mathrm{CH}_{2} \mathrm{~b}$. Although their frequen- 
Table V (Continued)

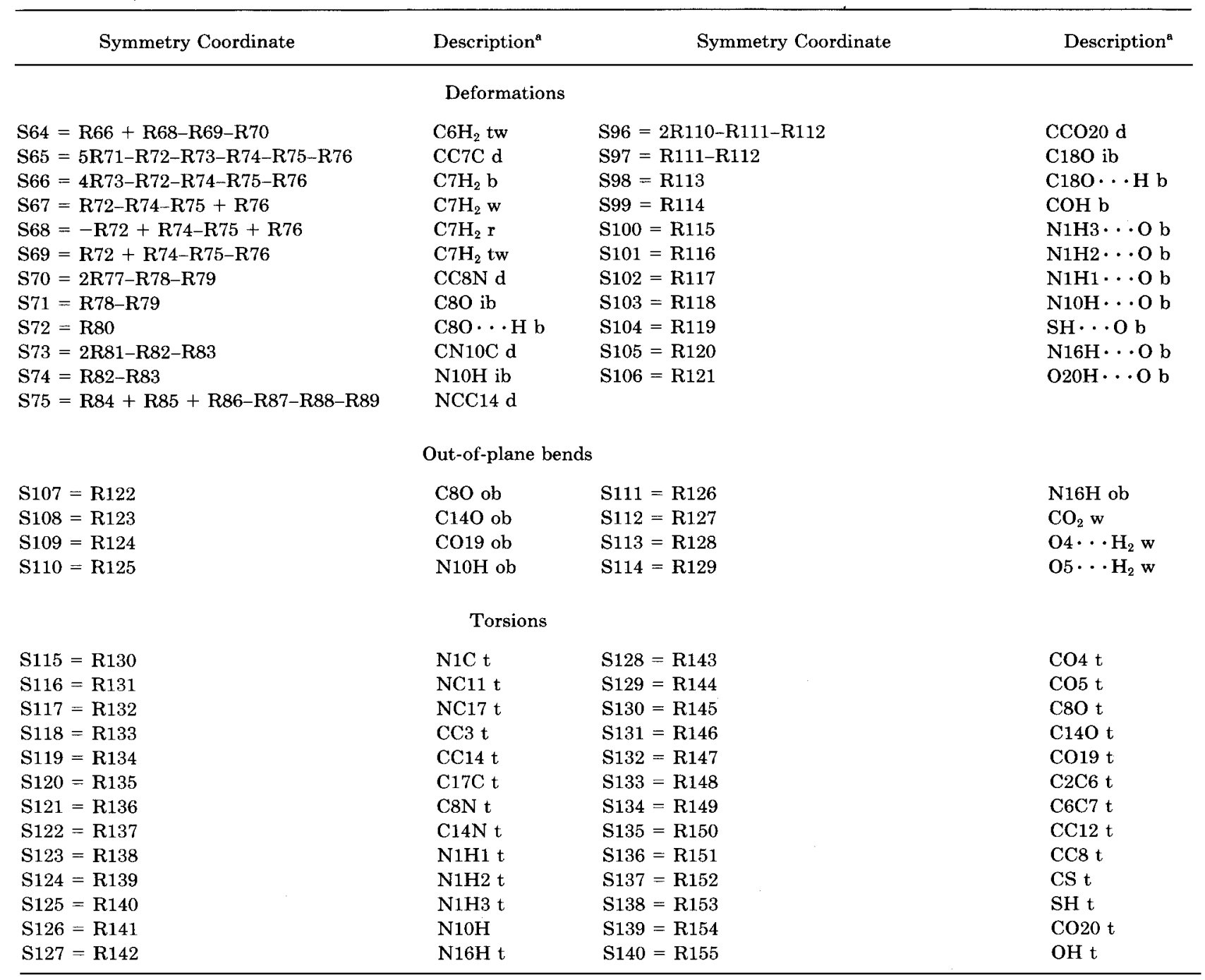

a s, Stretch; ss, symmetric stretch; as, antisymmetric stretch; b, bend; sb, symmetric bend; ab, antisymmetric bend; ib, in-plane bend; ob, out-of-plane bend; $d$, deformation; $w$, wag; tw, twist; $r$, rock; $t$, torsion.

cies are generally reproduced, specific assignments must await more detailed information beyond the present assumption of equal $\mathrm{HCH} b$ force constants.

The $\mathrm{CO}_{2}^{-}$ss mode, calculated at $1395 \mathrm{~cm}^{-1}$ with a contribution at $1404 \mathrm{~cm}^{-1}$, is clearly assignable to the strong band at $1396 \mathrm{~cm}^{-1}$, the mixed mode with $\mathrm{C}_{6} \mathrm{H}_{2}$ wag (w) being assignable to the weak band at $1413 \mathrm{~cm}^{-1}$. These mode compositions are reversed in GSD, at 1401 (1412) and $1393(1398) \mathrm{cm}^{-1}$, and it is interesting to see that the observed relative intensities follow this pattern, in fact being reversed in the Raman.

The $\mathrm{C}$ - $\mathrm{O}$ s and $\mathrm{COH} b$ modes could be expected to fall in this region, based on the analysis of glycine. ${ }^{13}$ However, as we noted above, the $\mathrm{COH} b$ force constant had to be reduced significantly in order to explain the absence of a shift of the CO19 s frequency in GSD. We expect, therefore, that it will mainly be $\mathrm{C}-\mathrm{O}$ s that contributes in this region. For the isolated glycine molecule, observed bands at 1253,1131 , and $1101 \mathrm{~cm}^{-1}$ contain $\mathrm{C}-\mathrm{O}$ s contributions. ${ }^{13}$ For the glycine conformation found in GSH, these modes are calculated at 1308, 1156, and $844 \mathrm{~cm}^{-1}$ for the isolated molecule and at 1363, 1226, and $850 \mathrm{~cm}^{-1}$ for the molecule with two water molecules hydrogen bonded to it. $^{13}$ Using the $\mathrm{C}-\mathrm{O}$ s force constant from the latter system, we calculate a main CO20 s mode at $\sim 1337 \mathrm{~cm}^{-1}$, to which strong ir and Raman bands at $\sim 1335 \mathrm{~cm}^{-1}$ can be assigned, and a small contribution to a calculated $1368 \mathrm{~cm}^{-1}$ $\mathrm{C}_{17} \mathrm{H}_{2}$ w mode, to which a strong Raman band at $1368 \mathrm{~cm}^{-1}$ can be assigned. Another major CO20 s 
Table VI Observed and Calculated Frequencies (in $\mathrm{cm}^{-1}$ ) of GSH

\begin{tabular}{|c|c|c|c|c|c|c|}
\hline \multicolumn{2}{|c|}{ Observed $^{\mathrm{a}}$} & \multicolumn{5}{|r|}{ Calculated } \\
\hline Raman & IR & A & $\mathrm{B}_{1}$ & $\mathbf{B}_{2}$ & $\mathrm{~B}_{3}$ & Potential Energy Distribution ${ }^{\mathrm{b}}$ \\
\hline & \multirow{2}{*}{$3348 \mathrm{~m}$} & $\{3346$ & 3346 & 3346 & 3346 & $\mathrm{OH} \mathrm{s}(108)$ \\
\hline & & $\{3344$ & 3344 & 3344 & 3344 & N10H s(99) \\
\hline & $3251 \mathrm{~m}$ & 3262 & 3262 & 3262 & 3262 & $\mathrm{~N} 16 \mathrm{H}$ s $(99)$ \\
\hline & \multirow[t]{2}{*}{$3130 \mathrm{~m}$} & 3122 & 3122 & 3122 & 3122 & $\mathrm{NH}_{3}$ as1(81) $\mathrm{NH}_{3}$ as $2(17)$ \\
\hline & & 3111 & 3111 & 3111 & 3111 & $\mathrm{NH}_{3}$ as2(81) $\mathrm{NH}_{3}$ as1(18) \\
\hline & \multirow[t]{2}{*}{$3031 \mathrm{~m}$} & 3027 & 3027 & 3027 & 3027 & $\mathrm{NH}_{3} \mathrm{ss}(98)$ \\
\hline & & 3022 & 3022 & 3022 & 3022 & ${\mathrm{C} 17 \mathrm{H}_{2}}_{2}$ as (77) $\mathrm{C} 17 \mathrm{H}_{2} \mathrm{ss}(22)$ \\
\hline $2997 \mathrm{~m}$ & & 2995 & 2995 & 2995 & 2995 & $\mathrm{C} 7 \mathrm{H}_{2}$ as (61) $\mathrm{C} 6 \mathrm{H}_{2}$ as(38) \\
\hline \multirow[t]{2}{*}{$2989 \mathrm{sh}$} & $2990 \mathrm{sh}$ & 2992 & 2992 & 2992 & 2992 & $\mathrm{C} 6 \mathrm{H}_{2}$ as $(61) \mathrm{C} 7 \mathrm{H}_{2}$ as $(38)$ \\
\hline & $2969 \mathrm{w}$ & 2979 & 2979 & 2979 & 2979 & $\mathrm{C} 12 \mathrm{H}_{2}$ as $(100)$ \\
\hline \multirow[t]{2}{*}{2948 vs } & $2945 \mathrm{mw}$ & 2953 & 2953 & 2953 & 2953 & $\mathrm{C} 17 \mathrm{H}_{2}$ ss(78) $\mathrm{C}_{17} \mathrm{H}_{2}$ as(24) \\
\hline & $2935 \mathrm{sh}$ & 2937 & 2937 & 2937 & 2937 & $\mathrm{C}_{12} \mathrm{H}_{2} \mathrm{ss}(100)$ \\
\hline \multirow{4}{*}{$2907 \mathrm{~m}$} & \multirow{2}{*}{$2906 \mathrm{w}$} & $\{2928$ & 2928 & 2928 & 2928 & $\mathrm{C} 6 \mathrm{H}_{2} \mathrm{ss}(71) \mathrm{C} 7 \mathrm{H}_{2} \mathrm{ss}(28)$ \\
\hline & & 2925 & 2925 & 2925 & 2925 & $\mathrm{C} 7 \mathrm{H}_{2} \mathrm{ss}(71) \mathrm{C}_{2} \mathrm{H}_{2} \mathrm{ss}(28)$ \\
\hline & \multirow{2}{*}{$2863 \mathrm{w}$} & $\{2866$ & 2866 & 2866 & 2866 & $\mathrm{C} 2 \mathrm{H}$ s(99) \\
\hline & & $\{2864$ & 2864 & 2864 & 2864 & C11H s(99) \\
\hline $2525 \mathrm{~s}$ & $\left.\begin{array}{l}2625 \mathrm{w} \\
2524 \mathrm{~m}\end{array}\right\}$ & 2531 & 2531 & 2531 & 2531 & SH s(100) \\
\hline $1706 \mathrm{~m}$ & $1713 \mathrm{~s}$ & 1711 & 1713 & 1711 & 1713 & $\operatorname{CO} 19 \mathrm{~s}(92) \operatorname{CCO} 20 \mathrm{~d}(10)$ \\
\hline $1661 \mathrm{~m}$ & $1661 \mathrm{~s}$ & 1661 & 1656 & 1661 & 1662 & $\mathrm{C} 80 \mathrm{~s}(71) \mathrm{C} 8 \mathrm{~N} s(24) \mathrm{CC} 8 \mathrm{~N} d(10)$ \\
\hline \multirow[t]{2}{*}{$1630 \mathrm{~s}$} & 1627 vs & 1628 & 1629 & 1628 & 1628 & $\mathrm{C} 14 \mathrm{O} \mathrm{s}(72) \mathrm{C} 14 \mathrm{~N} \mathrm{~s}(23)$ \\
\hline & $1615 \mathrm{~m}$ & 1618 & 1619 & 1619 & 1618 & $\mathrm{NH}_{3}$ ab2(59) $\mathrm{NH}_{3} \mathbf{r} 1(21) \mathrm{NH}_{3}$ ab1(10) \\
\hline \multirow{2}{*}{$1597 \mathrm{sh}$} & \multirow{2}{*}{1600 vs } & 1603 & 1601 & 1601 & 1603 & $\mathrm{CO}_{2}$ as $(99) \mathrm{CO}_{2} \mathrm{r}(11)$ \\
\hline & & 1595 & 1595 & 1595 & 1595 & $\mathrm{NH}_{3}$ ab1(63) $\mathrm{NH}_{3} \mathbf{r} 2(22) \mathrm{NH}_{3}$ ab2(10) \\
\hline $1560 \mathrm{w}$ & $1559 \mathrm{~ms}$ & 1556 & 1555 & 1556 & $\mathbf{1} 556$ & $\mathrm{~N} 16 \mathrm{H}$ ib(47) C14N s(24) CC14 s(14) C14O ib(12) \\
\hline $1541 \mathrm{w}$ & \multirow[t]{3}{*}{$1537 \mathrm{~s}$} & 1542 & 1542 & 1542 & 1543 & $\mathrm{~N} 10 \mathrm{H}$ ib(53) C8N s(19) CC8 s(11) \\
\hline \multirow[t]{2}{*}{$1492 \mathrm{w}$} & & 1494 & 1495 & 1495 & 1494 & $\mathrm{NH}_{3} \mathrm{sb}(84)$ \\
\hline & & 1451 & 1451 & 1451 & 1451 & $\mathrm{C}_{6} \mathrm{H}_{2} \mathrm{~b}(63)$ \\
\hline $1456 \mathrm{w}$ & $1453 \mathrm{~m}$ & 1444 & 1444 & 1444 & 1444 & $\mathrm{C}_{12} \mathrm{H}_{2} \mathrm{~b}(91)$ \\
\hline \multirow[t]{2}{*}{$1443 \mathrm{~ms}$} & \multirow[t]{2}{*}{$1442 \mathrm{w}\}$} & 1442 & 1442 & 1442 & 1442 & $\mathrm{C} 17 \mathrm{H}_{2} \mathrm{~b}(87)$ \\
\hline & & 1436 & 1436 & 1436 & 1436 & $\mathrm{C} 7 \mathrm{H}_{2} \mathrm{~b}(82)$ \\
\hline $1414 w$ & $1413 \mathrm{w}$ & 1404 & 1404 & 1404 & 1404 & $\mathrm{C} \mathrm{H}_{2} \mathrm{w}(21) \mathrm{C}_{6} \mathrm{H}_{2} \mathrm{~b}(16) \mathrm{CO}_{2} \mathrm{ss}(16) \mathrm{CC} 3 \mathrm{~s}(16)$ \\
\hline $1397 \mathrm{~s}$ & $1396 \mathrm{~s}$ & 1395 & 1396 & 1396 & 1395 & $\mathrm{CO}_{2} \mathrm{ss}(45) \mathrm{CO}_{2} \mathrm{~b}(24) \mathrm{C} 6 \mathrm{H}_{2} \mathrm{tw}(12) \mathrm{CC} 3 \mathrm{~s}(10)$ \\
\hline $1368 \mathrm{~s}$ & $1367 \mathrm{w}$ & 1367 & 1369 & 1367 & 1369 & $\begin{array}{l}\mathrm{C} 17 \mathrm{H}_{2} \mathrm{w}(34) \mathrm{C} 17 \mathrm{C} s(14) \mathrm{CO} 20 \mathrm{~s}(11) \mathrm{C}_{17 \mathrm{H}_{2} \mathrm{~b}(10)} \\
\mathrm{CC} 14 \mathrm{~s}(10)\end{array}$ \\
\hline $1342 \mathrm{sh}$ & $1351 \mathrm{w}$ & 1354 & 1355 & 1354 & 1355 & $\mathrm{C} 7 \mathrm{H}_{2} \mathrm{w}(28) \mathrm{C}_{6} \mathrm{H}_{2} \mathrm{tw}(17) \mathrm{CC} 8 \mathrm{~s}(13)$ \\
\hline $1342 \mathrm{sh}$ & & 1342 & 1342 & 1341 & 1342 & $\mathrm{H}^{\alpha}[\mathrm{C} 2] \mathrm{b} 2(32) \mathrm{NH}_{3} \mathrm{r} 1(13) \mathrm{C} 6 \mathrm{H}_{2} \mathrm{w}(10)$ \\
\hline & & & 1339 & & 1339 & $\mathrm{CO} 20 \mathrm{~s}(21) \mathrm{N} 16 \mathrm{H} \mathrm{ib}(14) \mathrm{C} 17 \mathrm{C} \mathrm{s}(10)$ \\
\hline $1336 \mathrm{~s}$ & $1333 \mathrm{~s}$ & 1334 & & 1334 & & CO20 s(35) CO19 ib(16) C17C s(15) N16H ib(13) \\
\hline $1310 \mathrm{~s}$ & $1314 \mathrm{w}$ & 1321 & & 1321 & & $\mathrm{C}_{17 \mathrm{H}_{2}} \mathrm{w}(43) \mathrm{H}^{\alpha}[\mathrm{C} 11] \mathrm{b} 2(15) \mathrm{N} 16 \mathrm{H}$ ib(14) \\
\hline & $1014 \mathrm{~W}$ & & 1314 & & 1314 & 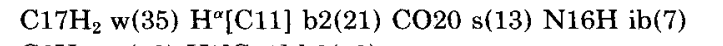 \\
\hline & $1290 \mathrm{sh}$ & $\{1300$ & 1299 & 1300 & 1299 & $\mathrm{C}^{2} \mathrm{H}_{2}$ tw $(12) \mathrm{H}^{\alpha}[\mathrm{C} 11]$ b2(10) \\
\hline & & 1291 & 1290 & 1291 & 1291 & $\mathrm{NH}_{3} \mathrm{r} 2(34)$ \\
\hline $1281 \mathrm{~s}$ & $1279 \mathrm{~s}$ & 1275 & 1275 & 1275 & 1275 & $\mathrm{C}^{17 \mathrm{H}_{2}} \operatorname{tw}(50) \mathrm{H}^{\alpha}[\mathrm{C} 11] \mathrm{b} 2(11)$ \\
\hline $1255 \mathrm{w}$ & & 1260 & 1260 & 1260 & 1260 & $\mathrm{C} 12 \mathrm{H}_{2} \mathrm{w}(48) \mathrm{H}^{\alpha}[\mathrm{C} 11] \mathrm{b} 1(21) \mathrm{C} 12 \mathrm{H}_{2} \mathrm{tw}(11)$ \\
\hline & & 1254 & 1254 & 1254 & 1254 & $\mathrm{H}^{\alpha}[\mathrm{C} 11] \mathbf{b} 2(29) \mathrm{C} 17 \mathrm{H}_{2} \mathrm{tw}(25) \mathrm{N} 16 \mathrm{H} \mathrm{ib}(12)$ \\
\hline & $1249 \mathrm{~s}$ & $\{1252$ & 1252 & 1252 & 1252 & $\mathrm{C}^{2} \mathrm{H}_{2} \mathrm{w}(23) \mathrm{C}^{2} \mathrm{H}_{2} \mathrm{tw}(22) \mathrm{H}^{\alpha}[\mathrm{C} 2] \mathrm{b} 1(21) \mathrm{C} \mathrm{H}_{2}$ tw $(10)$ \\
\hline $1235 \mathrm{w}$ & $1238 \mathrm{sh}$ & 1240 & 1241 & 1241 & 1240 & $\mathrm{NH}_{3} \mathbf{r} 1(37) \mathrm{H}^{\alpha}[\mathrm{C} 2]$ b2(32) \\
\hline $1224 \mathrm{~ms}$ & $1223 \mathrm{sh}$ & 1217 & 1216 & 1217 & 1217 & $\mathrm{C} 6 \mathrm{H}_{2}$ tw(23) $\mathrm{C} 12 \mathrm{H}_{2}$ tw(13) $\mathrm{C} \mathrm{H}_{2} \operatorname{tw}(12)$ \\
\hline $1200 \mathrm{vw}$ & $1203 \mathrm{sh}$ & 1201 & 1201 & 1201 & 1201 & $\mathrm{C}_{12} \mathrm{H}_{2}$ tw $(25) \mathrm{C}_{7} \mathrm{H}_{2} \mathrm{w}(12)$ \\
\hline $1170 \mathrm{~ms}$ & $1169 \mathrm{~m}$ & 1174 & 1174 & 1174 & 1174 & $\mathrm{H}^{\alpha}[\mathrm{C} 11] \mathrm{b} 1(43) \mathrm{C}^{2} \mathrm{H}_{2} \mathrm{w}(27) \mathrm{NC} 17 \mathrm{~s}(15)$ \\
\hline $1143 \mathrm{~m}$ & $1143 \mathrm{mw}$ & 1149 & 1149 & 1149 & 1149 & $\mathrm{H}^{\alpha}[\mathrm{C} 2] \mathrm{b} 1(35) \mathrm{C} \mathrm{H}_{2} \mathrm{tw}(23) \mathrm{C} \mathrm{H}_{2} \mathrm{w}(20) \mathrm{C} 6 \mathrm{C} 7 \mathrm{~s}(11)$ \\
\hline $1121 \mathrm{sh}$ & $1123 \mathrm{sh}$ & 1125 & 1125 & 1125 & 1125 & $\begin{array}{l}\mathrm{H}^{\alpha}[\mathrm{C} 11] \mathrm{b} 1(15) \mathrm{C} 12 \mathrm{H}_{2} \mathrm{tw}(13) \mathrm{CC} 12 \mathrm{~s}(13) \mathrm{C}_{12} \mathrm{H}_{2} \mathrm{tw}(13) \\
\mathrm{NC} 11 \mathrm{~s}(10)\end{array}$ \\
\hline $1115 \mathrm{~m}$ & $1115 \mathrm{~m}$ & 1112 & 1112 & 1112 & 1112 & $\mathrm{NC} 17 \mathrm{~s}(11) \mathrm{N} 1 \mathrm{C} s(10) \mathrm{C} 2 \mathrm{C} 6 \mathrm{~s}(10)$ \\
\hline & & 1097 & 1097 & 1097 & 1097 & $\mathrm{NC} 17 \mathrm{~s}(22) \mathrm{C}_{12} \mathrm{H}_{2}$ tw(12) NC11 s(11) CC14 s(10) \\
\hline $1074 \mathrm{mw}$ & $1074 \mathrm{~s}$ & 1068 & 1068 & 1068 & 1068 & $\mathrm{C} 6 \mathrm{C} 7 \mathrm{~s}(22) \mathrm{C} 2 \mathrm{C} 6 \mathrm{~s}(20) \mathrm{C} \mathrm{H}_{2} \mathrm{r}(11)$ \\
\hline $1041 \mathrm{~ms}$ & $1046 \mathrm{sh}$ & 1052 & 1053 & 1052 & 1053 & $\mathrm{C}_{17 \mathrm{H}_{2}} \mathrm{r}(41) \mathrm{CO} 19 \mathrm{ob}(19) \mathrm{COH} b(13)$ \\
\hline
\end{tabular}


Table VI (Continued)

\begin{tabular}{|c|c|c|c|c|c|c|}
\hline \multicolumn{2}{|c|}{ Observed $^{a}$} & \multicolumn{5}{|r|}{ Calculated } \\
\hline Raman & IR & A & $\mathrm{B}_{1}$ & $\mathrm{~B}_{2}$ & $\mathrm{~B}_{3}$ & Potential Energy Distribution ${ }^{\mathbf{b}}$ \\
\hline $1029 \mathrm{sh}$ & $1030 \mathrm{w}$ & 1028 & 1024 & 1028 & 1024 & $\mathrm{COH} \mathrm{b}(45) \operatorname{CO} 20 \mathrm{t}(13)$ \\
\hline $1014 \mathrm{~ms}$ & $1013 \mathrm{mw}$ & 1004 & 1007 & 1004 & 1007 & $\mathrm{CC1} 2 \mathrm{~s}(14) \mathrm{CSH} b(13)$ \\
\hline $989 \mathrm{mw}$ & $989 \mathrm{sh}$ & 998 & 998 & 998 & 998 & $\mathrm{CC} 12 \mathrm{~s}(24) \mathrm{C} \mathrm{H}_{2} \mathrm{r}(14)$ \\
\hline $953 \mathrm{mw}$ & $951 \mathrm{w}$ & 956 & 956 & 956 & 956 & $\mathrm{C} \mathrm{H}_{2} \mathbf{r}(27) \mathrm{CSH} b(12) \mathrm{N} 1 \mathrm{C} \mathrm{s}(12)$ \\
\hline $930 \mathrm{~ms}$ & $930 \mathrm{~m}$ & 927 & 927 & 927 & 927 & $\mathrm{CSH} b(25) \mathrm{C} \mathrm{H}_{2} \mathbf{r}(19) \mathrm{NC} 11 \mathrm{~s}(12) \mathrm{N} 1 \mathrm{C} \mathrm{s}(10)$ \\
\hline $917 \mathrm{~m}$ & $917 \mathrm{w}$ & 905 & 905 & 905 & 906 & $\mathrm{C} 8 \mathrm{~N} s(10)$ \\
\hline $885 \mathrm{~s}$ & $884 \mathrm{vw}$ & 892 & 890 & 890 & 892 & CC3 s(41) C6C7 s(14) \\
\hline \multirow{2}{*}{$868 \mathrm{~m}$} & \multirow{2}{*}{$867 w$} & 873 & 871 & 873 & 871 & $\mathrm{C} 14 \mathrm{~N}$ s(11) CC8 s(11) \\
\hline & & 863 & 865 & 863 & 865 & $\mathrm{CO} 20 \mathrm{~s}(29) \mathrm{C} 17 \mathrm{C} \mathrm{s}(26) \mathrm{COH} b(14)$ \\
\hline $828 \mathrm{~ms}$ & $828 \mathrm{~m}$ & 828 & 821 & 828 & 821 & $\mathrm{COH} \mathrm{b(16)} \mathrm{NC17C} \mathrm{d(10)}$ \\
\hline $812 \mathrm{mw}$ & $811 \mathrm{w}$ & 811 & 810 & 810 & 811 & $\mathrm{~N} 1 \mathrm{C} s(25) \mathrm{C} \mathrm{H}_{2} \mathbf{r}(18)$ \\
\hline \multirow[t]{2}{*}{$775 \mathrm{~m}$} & & 786 & 786 & 786 & 786 & $\mathrm{CO}_{2} \mathrm{~b}(34) \mathrm{CO}_{2} \mathrm{w}(23) \mathrm{CO}_{2} \cdot \mathrm{ss}(18)$ \\
\hline & $764 \mathrm{~m}$ & 763 & 761 & 763 & 761 & $\mathrm{C} 12 \mathrm{H}_{2} \mathrm{r}(20) . \mathrm{CSH} b(15)$ \\
\hline $756 \mathrm{sh}$ & $759 \mathrm{sh}$ & 745 & 744 & 745 & 744 & ${\mathrm{C} 12 \mathrm{H}_{2}}_{2}$ (39) $\mathrm{CSH} b(14)$ \\
\hline \multirow[t]{5}{*}{$722 \mathrm{w}$} & $720 \mathrm{mw}$ & 723 & 723 & 723 & 723 & $\mathrm{CO}_{2} \mathrm{~b}(24) \mathrm{CO}_{2} \mathrm{w}(17)$ \\
\hline & & 704 & & 704 & & $\begin{array}{l}\mathrm{C} 14 \mathrm{~N} \mathrm{t}(41) \mathrm{COH} b(16) \mathrm{OH} \cdot \cdots \mathrm{O} \text { b(11) } \mathrm{N} 16 \mathrm{H} \text { ob(10) } \\
\mathrm{C} 8 \mathrm{~N} \mathrm{t}(10)\end{array}$ \\
\hline & $691 \mathrm{~m}$ & & 700 & & 700 & C14N t(49) C8N t(21) N16H ob(13) \\
\hline & & & 692 & & 692 & $\mathrm{C} 8 \mathrm{~N} \mathrm{t}(34) \mathrm{C} 14 \mathrm{~N} \mathrm{t}(23) \mathrm{N} 16 \mathrm{H}$ ob(18) \\
\hline & & 691 & & 691 & & $\mathrm{C} 8 \mathrm{~N}$ t(52) $\mathrm{C} 14 \mathrm{~N} \mathrm{t}(16) \mathrm{N} 10 \mathrm{H}$ ob(13) N16H ob(12) \\
\hline \multirow{3}{*}{679 vs } & & & 679 & & 679 & CS s(46) C8N t(19) C14O ob(12) N10H ob(11) \\
\hline & $682 \mathrm{sh}$ & 678 & & 678 & & $\mathrm{CS}$ s(55) $\mathrm{C} 14 \mathrm{O}$ ob(12) $\mathrm{C} 8 \mathrm{~N} \mathrm{t}(10)$ \\
\hline & & 648 & & 648 & & $\mathrm{C} 8 \mathrm{O}$ ob(17) $\mathrm{OH} \cdots \mathrm{O} b(11) \mathrm{COH} b(11)$ \\
\hline \multirow[t]{2}{*}{$659 \mathrm{w}$} & $657 \mathrm{w}$ & & & & & $\mathrm{N} 10 \mathrm{H}$ ob(11) CO20 t(10) \\
\hline & & & 649 & & 649 & CS s(19) N10H ob(13) C8O ob(11) \\
\hline 642 vw & $643 \mathrm{~m}$ & 642 & 643 & 642 & 643 & $\operatorname{CC} 8 \mathrm{~s}(10)$ \\
\hline \multirow[t]{6}{*}{$624 \mathrm{~s}$} & $617 \mathrm{~m}$ & 625 & 624 & 625 & 624 & $\mathrm{C} 80$ ob(24) CC7C d(15) CCO20 d(15) \\
\hline & & & & & & $\mathrm{CO} 20 \mathrm{t}(12) \mathrm{COH} b(10) \mathrm{OH} \cdots \mathrm{Ob}(10)$ \\
\hline & & 588 & 592 & 588 & 592 & $\begin{array}{l}\mathrm{CO} 19 \text { ob(18) } \mathrm{C} 80 \mathrm{ib}(14) \mathrm{C} 8 \mathrm{O} \text { ob(14) } \mathrm{C} 17 \mathrm{H}_{2} \mathrm{r}(13) \\
\mathrm{CC} 8 \mathrm{~s}(10)\end{array}$ \\
\hline & & & 569 & & 569 & $\operatorname{CC8N} d(19) \mathrm{N} 1 \mathrm{C} t(10)$ \\
\hline & & 565 & & 566 & & CC8N d(19) C14O ib(12) \\
\hline & & 556 & 555 & 557 & 554 & N1C t(27) \\
\hline \multirow[t]{2}{*}{$548 \mathrm{~m}$} & $550 \mathrm{~s}$ & 544 & & 544 & & $\mathrm{C} 8 \mathrm{O}$ ob(14) N1C t(12) NCC14 d(11) \\
\hline & & & 548 & & 547 & $\mathrm{C} 8 \mathrm{O}$ ob(15) N1C t(13) CO19 ob(12) \\
\hline \multirow[t]{2}{*}{$518 \mathrm{w}$} & $522 \mathrm{w}$ & 531 & 531 & 531 & 531 & $\mathrm{CO}_{2} \mathrm{r}(31) \mathrm{N} 1 \mathrm{C} \mathrm{s}(30)$ \\
\hline & & & 498 & & 498 & $\mathrm{COH} b(31) \mathrm{CO} 19 \mathrm{ib}(29) \mathrm{OH} \cdots \mathrm{O} b(25) \mathrm{CO} 20 \mathrm{t}(15)$ \\
\hline $477 \mathrm{w}$ & $478 \mathrm{~m}$ & 487 & & 487 & & $\begin{array}{l}\mathrm{COH} \text { b(33) CO19 ib(29) OH } \cdots \text { O b(27) CO20 t(16) } \\
\text { C14N t(15) CO19 ob(14) } \mathrm{C}_{17 \mathrm{H}_{2}} \mathbf{r ( 1 1 )}\end{array}$ \\
\hline $446 \mathrm{w}$ & & 444 & 446 & 445 & 445 & $\mathrm{CC} 6 \mathrm{C} \mathrm{d}(21) \mathrm{CC} 7 \mathrm{C} \mathrm{d}(20)$ \\
\hline \multirow[t]{2}{*}{$429 \mathrm{vw}$} & & & 423 & & 423 & $\mathrm{C} 12$ b1(14) CCO20 d(14) CCS d(10) \\
\hline & & 418 & & 417 & & CCO20 d(17) N16H ob(12) C12 b1(12) CO19 ib(11) \\
\hline $401 \mathrm{vs}$ & & 406 & 404 & 404 & 406 & $\mathrm{C} 3 \mathrm{~b} 2(22) \mathrm{NCC} 3 \mathrm{~d}(19) \mathrm{CO}_{2} \mathbf{r}(13) \mathrm{C} 3 \mathrm{~b} 1(13)$ \\
\hline 360 sh & & 351 & 355 & 352 & 354 & C12 b2(21) C12 b1(10) CC14N d(10) C14O ib(10) \\
\hline $350 \mathrm{~m}$ & & 343 & 331 & 343 & 331 & $\mathrm{CCO} 20 \mathrm{~d}(27) \mathrm{NC} 17 \mathrm{C} \mathrm{d}(17)$ \\
\hline \multirow{9}{*}{$303 \mathrm{~m}$} & & & 297 & 299 & & NCC3 d(15) CN16C d(12) \\
\hline & & 294 & & & 292 & $\mathrm{CN} 16 \mathrm{C} d(20) \mathrm{NCC} 3 \mathrm{~d}(11)$ \\
\hline & & 282 & 281 & 282 & 281 & $\mathrm{SH} \cdots \mathrm{Ob}(77)$ \\
\hline & & 267 & 273 & 273 & 267 & C3 b1(19) NCC3 d(13) CN16C d(12) $\mathrm{CO}_{2} \mathbf{r}(10)$ \\
\hline & & 260 & 261 & 260 & 261 & $\mathrm{C} 12 \mathrm{~b} 2(32)$ \\
\hline & & 246 & 242 & 241 & 247 & C3 b1(37) \\
\hline & & 213 & 214 & 213 & 214 & $\mathrm{CC} 14 \mathrm{~N} d(14) \mathrm{CN} 16 \mathrm{C}$ d(11) N10H ob(10) \\
\hline & & 205 & 207 & 207 & 205 & C3 b2(22) CN10C d(13) CC6C d(11) CC14N d(11) \\
\hline & & 179 & 179 & 179 & 180 & $\mathrm{CN} 10 \mathrm{C} d(27) \operatorname{CCS} \mathrm{d}(20)$ \\
\hline
\end{tabular}

${ }^{\mathrm{a}} \mathrm{s}$, Strong; m, medium; w, weak; sh, shoulder.

${ }^{b}$ Contributions to potential energy distribution of 10 or larger. s, Stretch; ss, symmetric stretch; as, antisymmetric stretch; $b$, bend; sb, symmetric bend; ab, antisymmetric bend; ib, in-plane bend; ob, out-of-plane bend; $d$, deformation; $w$, wag; tw, twist; $r$, rock; $\mathrm{t}$, torsion. 
Table VII Observed and Calculated Frequencies (in $\mathrm{cm}^{-1}$ ) of GSD

\begin{tabular}{|c|c|c|c|c|c|c|}
\hline \multicolumn{2}{|c|}{ Observed $^{\mathrm{a}}$} & \multicolumn{5}{|r|}{ Calculated } \\
\hline Raman & IR & A & $\mathrm{B}_{1}$ & $\mathrm{~B}_{2}$ & $\mathrm{~B}_{3}$ & Potential Energy Distribution ${ }^{b}$ \\
\hline & & 3022 & 3022 & 3022 & 3022 & $\mathrm{C}_{1} 7 \mathrm{H}_{2}$ as(77) $\mathrm{C} 17 \mathrm{H}_{2} \mathrm{ss}(22)$ \\
\hline $2997 w$ & & 2995 & 2995 & 2995 & 2995 & $\mathrm{C} 7 \mathrm{H}_{2}$ as $(60) \mathrm{C}_{6} \mathrm{H}_{2}$ as $(39)$ \\
\hline $2989 \mathrm{w}$ & $2988 \mathrm{w}$ & 2992 & 2992 & 2992 & 2992 & $\mathrm{C} \mathrm{H}_{2}$ as $(60) \mathrm{C} 7 \mathrm{H}_{2}$ as $(39)$ \\
\hline $2970 \mathrm{sh}$ & $2970 \mathrm{w}$ & 2979 & 2979 & 2979 & 2979 & $\mathrm{C} 12 \mathrm{H}_{2}$ as $(100)$ \\
\hline \multirow[t]{2}{*}{2949 vs } & $2948 \mathrm{mw}$ & 2953 & 2953 & 2953 & 2953 & $\mathrm{C}_{17} \mathrm{H}_{2} \mathrm{ss}(78) \mathrm{C}_{1} 7 \mathrm{H}_{2}$ as (24) \\
\hline & $2940 \mathrm{sh}$ & 2937 & 2937 & 2937 & 2937 & $\mathrm{C} 12 \mathrm{H}_{2} \mathrm{ss}(100)$ \\
\hline \multirow{10}{*}{$2909 w$} & $2907 \mathrm{w}$ & 2928 & 2928 & 2928 & 2928 & $\mathrm{C}_{6} \mathrm{H}_{2} \mathrm{ss}(71) \mathrm{C}_{7} \mathrm{H}_{2} \mathrm{ss}(28)$ \\
\hline & $2907 \mathrm{w}$ & 2925 & 2925 & 2925 & 2925 & $\mathrm{C} 7 \mathrm{H}_{2} \mathrm{ss}(72) \mathrm{C} 6 \mathrm{H}_{2} \mathrm{ss}(28)$ \\
\hline & & 2866 & 2866 & 2866 & 2866 & $\mathrm{C} 2 \mathrm{H} \mathrm{s}(99)$ \\
\hline & $2865 \mathrm{w}$ & 2864 & 2864 & 2864 & 2864 & $\mathrm{C} 11 \mathrm{H} \mathrm{s}(99)$ \\
\hline & $2495 \mathrm{~ms}$ & 2462 & 2462 & 2462 & 2462 & N10D s(98) \\
\hline & $2434 w$ & 2443 & 2443 & 2443 & 2443 & OD s(108) \\
\hline & $2396 \mathrm{~m}$ & 2403 & 2402 & 2403 & 2402 & N16D s(97) \\
\hline & $2346 \mathrm{~m}$ & 2316 & 2316 & 2316 & 2316 & $\mathrm{ND}_{3} \operatorname{as} 1(74) \mathrm{ND}_{3}$ as $2(24)$ \\
\hline & & 2310 & 2310 & 2310 & 2310 & $\mathrm{ND}_{3}$ as $2(74) \mathrm{ND}_{3}$ as1(24) \\
\hline & $2189 \mathrm{w}$ & 2174 & 2174 & 2174 & 2174 & $\mathrm{ND}_{3} \mathrm{ss}(98)$ \\
\hline $\begin{array}{l}1865 \mathrm{w} \\
1837 \mathrm{~m}\end{array}$ & $1837 \mathrm{~m}\}$ & 1821 & 1821 & 1821 & 1821 & $\operatorname{SD~s}(100)$ \\
\hline $1708 \mathrm{w}$ & $1713 \mathrm{~m}$ & 1709 & 1709 & 1709 & 1709 & $\operatorname{CO} 19 \mathrm{~s}(93) \operatorname{CCO} 20 \mathrm{~d}(10)$ \\
\hline $1655 \mathrm{~s}$ & $1656 \mathrm{~s}$ & 1657 & 1652 & 1657 & 1658 & $\mathrm{C} 80 \mathrm{~s}(71) \mathrm{C} 8 \mathrm{~N} s(24) \mathrm{CC} 8 \mathrm{~N} d(10)$ \\
\hline \multirow[t]{2}{*}{$1620 \mathrm{~s}$} & $1623 \mathrm{sh}$ & 1622 & 1624 & 1622 & 1623 & $\mathrm{C} 140 \mathrm{~s}(74) \mathrm{C} 14 \mathrm{~N} s(26)$ \\
\hline & $1604 \mathrm{vs}$ & 1602 & 1602 & 1602 & 1602 & $\mathrm{CO}_{2}$ as $(101) \mathrm{CO}_{2} \mathbf{r}(11)$ \\
\hline \multirow[t]{2}{*}{$1486 \mathrm{~m}$} & $1485 \mathrm{~m}$ & 1492 & 1492 & 1492 & 1492 & $\mathrm{C} 14 \mathrm{~N}$ s(31) CC14 s(28) C140 ib(18) \\
\hline & & & & & & N16D ib(12) NC17 s(11) \\
\hline \multirow[t]{2}{*}{$1466 \mathrm{~m}$} & $1464 \mathrm{~ms}$ & 1471 & 1471 & 1471 & 1471 & $\mathrm{C} \mathrm{H}_{2} \mathrm{~b}(25) \mathrm{CC} 8 \mathrm{~s}(22) \mathrm{C} 8 \mathrm{~N}$ s(17) $\mathrm{C} 8 \mathrm{O} \mathrm{ib}(11)$ \\
\hline & & 1450 & 1450 & 1450 & 1450 & $\mathrm{C}^{2} \mathrm{H}_{2} \mathrm{~b}(71) \mathrm{C} 2 \mathrm{C} 6 \mathrm{~s}(10)$ \\
\hline \multirow[t]{3}{*}{$1445 \mathrm{~m}$} & $1445 w$ & 1444 & 1444 & 1444 & 1444 & $\mathrm{C} 12 \mathrm{H}_{2} \mathrm{~b}(92)$ \\
\hline & $1439 \mathrm{sh}\}$ & 1440 & 1440 & 1440 & 1440 & $\mathrm{C} 17 \mathrm{H}_{2} b(90)$ \\
\hline & & 1422 & 1422 & 1422 & 1422 & $\mathrm{C}^{2} \mathrm{H}_{2} \mathrm{~b}(65) \mathrm{C} 8 \mathrm{~N} s(10)$ \\
\hline $1411 \mathrm{~s}$ & $1412 \mathrm{mw}$ & 1401 & 1401 & 1401 & 1401 & $\mathrm{CO}_{2} \mathrm{ss}(39) \mathrm{CC} 3 \mathrm{~s}(24) \mathrm{CO}_{2} \mathrm{ib}(22) \mathrm{C} \mathrm{H}_{2} \mathrm{w}(11) \mathrm{C}_{6} \mathrm{H}_{2} \mathrm{~b}(10)$ \\
\hline $1399 \mathrm{w}$ & $1397 \mathrm{~m}$ & 1393 & 1393 & 1393 & 1393 & $\mathrm{C}_{6} \mathrm{H}_{2} \mathrm{w}(27) \mathrm{CO}_{2} \mathrm{ss}(22) \mathrm{CO}_{2} \mathrm{ib}(12)$ \\
\hline \multirow{2}{*}{$1350 \mathrm{w}$} & $1349 \mathrm{~m}$ & $\{1360$ & 1362 & 1360 & 1362 & $\mathrm{C} 17 \mathrm{H}_{2} \mathrm{w}(48) \mathrm{C} 17 \mathrm{C} \mathrm{s}(23) \mathrm{CO} 20 \mathrm{~s}(18)$ \\
\hline & $1.349 \mathrm{~m}$ & $\{13339$ & 1339 & 1339 & 1339 & $\mathrm{H}^{\prime \prime}\left[(2]\right.$ b2(33) $\mathrm{C}^{2} 7 \mathrm{H}_{2} \mathrm{w}(24)\left(\mathrm{C} 6 \mathrm{H}_{2} \mathrm{tw}(23)\right.$ \\
\hline $1332 \mathrm{~s}$ & $1331 \mathrm{~s}$ & 1323 & 1321 & 1323 & 1321 & $\mathrm{C}_{17} \mathrm{H}_{2}$ w(39) CO20 s(36) CO19 ib(18) \\
\hline $1319 \mathrm{w}$ & $1316 \mathrm{mw}$ & 1320 & 1320 & 1320 & 1320 & $\mathrm{H}^{*}[\mathrm{C} 2]$ b2(37) $\mathrm{C}^{2} \mathrm{H}_{2} \mathrm{tw}(15) \mathrm{C}_{7} \mathrm{H}_{2} \mathrm{w}(13) \mathrm{C} 7 \mathrm{H}_{2} \mathrm{tw}(10)$ \\
\hline $1293 \mathrm{mw}$ & $1289 \mathrm{sh}$ & 1294 & 1294 & 1294 & 1294 & $\mathrm{H}^{\mathrm{a}}[\mathrm{C} 11]$ b2(78) \\
\hline $1276 \mathrm{~m}$ & $1273 \mathrm{~m}$ & 1270 & 1271 & 1270 & 1271 & $\mathrm{C} 17 \mathrm{H}_{2} \mathrm{tw}(87)$ \\
\hline \multirow[t]{2}{*}{$1249 \mathrm{w}$} & & 1262 & 1262 & 1262 & 1262 & $\mathrm{C} 12 \mathrm{H}_{2}$ w(44) $\mathrm{H}^{a}[\mathrm{C} 11]$ b1 $1(29)$ \\
\hline & $1239 \mathrm{w}$ & 1258 & 1258 & 1258 & 1258 & $\mathrm{C}^{2} \mathrm{H}_{2} w(26) \mathrm{H}^{\wedge}[\mathrm{C} 2]$ b1 (22) $\mathrm{C} 7 \mathrm{H}_{2} \mathrm{tw}(19) \mathrm{C}_{6} \mathrm{H}_{2} \mathrm{tw}(12)$ \\
\hline \multirow[t]{2}{*}{$1227 \mathrm{w}$} & $1225 \mathrm{mw}$ & 1224 & 1224 & 1224 & 1224 & $\mathrm{C}_{6} \mathrm{H}_{2}$ tw (18) $\mathrm{C} 7 \mathrm{H}_{2} \mathrm{tw}(17)$ \\
\hline & $1213 \mathrm{w}$ & 1216 & 1216 & 1216 & 1216 & $\mathrm{C} 12 \mathrm{H}_{2} \mathrm{tw}(47) \mathrm{NC} 11 \mathrm{~s}(11)$ \\
\hline $1195 \mathrm{vw}$ & $1194 \mathrm{w}$ & 1202 & 1202 & 1202 & 1202 & $\mathrm{ND}_{3}$ r2(19) C2C6 $\mathrm{s}(17) \mathrm{H}^{\prime \prime}[\mathrm{C} 2]$ b1(14) $\mathrm{C}_{6} \mathrm{H}_{2} \mathrm{w}(13)$ \\
\hline \multirow[t]{3}{*}{$1186 \mathrm{vw}$} & $1182 \mathrm{~s}$ & 1180 & 1180 & 1180 & 1180 & $\mathrm{C} 12 \mathrm{H}_{2}$ w $(40) \mathrm{H}^{\prime \prime}[\mathrm{C} 11]$ bl(36) \\
\hline & & 1155 & 1155 & 1155 & 1155 & $\mathrm{ND}_{3}$ abl(31) $\mathrm{ND}_{3}$ ab2(17) $\left(77 \mathrm{H}_{2} \operatorname{tw}(13)\right.$ \\
\hline & & 1151 & 1151 & 1151 & 1151 & $\mathrm{H}^{\times x}[\mathrm{C} 2]$ b1(28) NI):3 ab2(27) $\mathrm{C} 7 \mathrm{H}_{2}$ tw(11) $\mathrm{C} \mathrm{H}_{2}$ w(lo) \\
\hline $1129 \mathrm{w}$ & $1134 \mathrm{~m}$ & 1126 & 1126 & 1126 & 1126 & $\mathrm{C}_{6} \mathrm{H}_{2} \mathrm{r}(9) \mathrm{ND}_{3} \mathrm{sb}(8)$ \\
\hline \multirow{2}{*}{$\begin{array}{l}1129 \mathrm{w} \\
1117 \mathrm{~m}\end{array}$} & & $\int 111.6$ & 1116 & 1116 & 1116 & $\mathrm{ND}_{3}$ ab1(18) NC17 s(14) $\mathrm{ND}_{3}$ ab2(11) $\mathrm{H}^{\circ}[\mathrm{C} 11]$ b1(10) \\
\hline & $1117 \mathrm{sh}$ & $\{1115$ & 1115 & 1115 & 1115 & $\mathrm{ND}_{3}$ ab1(20) $\mathrm{ND}_{3}$ ab2(19) $\mathrm{C} 2 \mathrm{C} 6 \mathrm{~s}(11)$ \\
\hline $1098 \mathrm{mw}$ & $1098 \mathrm{mw}$ & 1090 & 1090 & 1090 & 1090 & $\mathrm{ND}_{3} \mathrm{sb}(15) \mathrm{NC17} \mathrm{s}(14) \mathrm{NC11} \mathrm{s}(12) \mathrm{C}_{12} \mathrm{H}_{2} \mathrm{tw}(12)$ \\
\hline \multirow{3}{*}{$1062 \mathrm{~m}$} & & $\{1068$ & 1069 & 1068 & 1069 & $\mathrm{C}_{17} \mathrm{H}_{2} \mathrm{r}(26) \mathrm{N} 16 \mathrm{D}$ ib(15) $\mathrm{CO} 19 \mathrm{ob}(13) \mathrm{ND}_{3} \mathrm{sb}(11)$ \\
\hline & $1063 \mathrm{~s}$ & 1066 & 1066 & 1066 & 1066 & $\mathrm{ND}_{3} \mathrm{sb}(38)$ \\
\hline & $1051 \mathrm{mw}$ & 1035 & 1035 & 1035 & 1035 & N10D ib(17) $\mathrm{ND}_{3} \mathrm{sb}(11)$ \\
\hline $1028 \mathrm{vw}$ & $1029 \mathrm{mw}$ & 1026 & 1026 & 1026 & 1026 & $\left.\mathrm{ND}_{3} \mathrm{r} 1(22) \mathrm{N} 10 \mathrm{I}\right) \mathrm{ib}(13)$ \\
\hline $998 \mathrm{sh}$ & $1000 \mathrm{vw}$ & 1004 & 1004 & 1004 & 1004 & $\mathrm{C} 6 \mathrm{C} 7 \mathrm{~s}(24) \mathrm{CC} 12 \mathrm{~s}(17)$ \\
\hline $982 \mathrm{~m}$ & & 982 & 980 & 982 & 980 & $\mathrm{~N} 16 \mathrm{~V}$ ib(34) $\mathrm{C}_{17} \mathrm{H}_{2} \mathbf{r}(13)$ \\
\hline $959 \mathrm{~s}$ & $959 \mathrm{~s}$ & 962 & 962 & 962 & 962 & CC12 s(20) N16D ib(16) N10D ib(12) $\mathrm{C}_{7} \mathrm{H}_{2} \mathbf{r}(11)$ \\
\hline $948 \mathrm{sh}$ & & 941 & 941 & 941 & 941 & $\mathrm{C} \mathrm{H}_{2} \mathbf{r}(24) \mathrm{N} 1 \mathrm{Cs}(21)$ \\
\hline $920 \mathrm{~m}$ & $919 \mathrm{mw}$ & 914 & 914 & 914 & 913 & $\mathrm{ND}_{3} \mathrm{r2(31)}$ \\
\hline
\end{tabular}


Table VII (Continued)

\begin{tabular}{|c|c|c|c|c|c|c|}
\hline \multicolumn{2}{|c|}{ Observed" } & \multicolumn{5}{|r|}{ Calculated } \\
\hline Raman & IR & A & $\mathrm{B}_{1}$ & $\mathbf{B}_{2}$ & $\mathbf{B}_{3}$ & Potential Fnergy IDistribution ${ }^{b}$ \\
\hline \multirow{2}{*}{$909 \mathrm{vw}$} & \multirow{2}{*}{$908 \mathrm{mw}$} & & 891 & & 891 & \multirow{2}{*}{$\begin{array}{l}\mathrm{CO} 20 \mathrm{~s}(18) \mathrm{COD} b(11) \mathrm{C} 17 \mathrm{C} s(11) \\
\mathrm{CO} 20 \mathrm{~s}(28) \mathrm{COD} b(16) \mathrm{C} / 17 \mathrm{C} s(16)\end{array}$} \\
\hline & & 888 & & 888 & & \\
\hline \multirow{2}{*}{$885 w$} & \multirow{2}{*}{888 sh } & 882 & & 882 & & $\mathrm{C} 8 \mathrm{~N} s(11)$ \\
\hline & & & 877 & & 877 & $\mathrm{CO} 20 \mathrm{~s}(15)$ \\
\hline $861 \mathrm{~m}$ & $859 \mathrm{mw}$ & 867 & 868 & 867 & 868 & $\mathrm{NC} 11 \mathrm{~s}(18) \mathrm{C}_{12} \mathrm{H}_{2} \mathrm{r}(15)$ \\
\hline $842 \mathrm{w}$ & $843 w$ & 848 & 847 & 845 & 848 & $\mathrm{CC} 3 \mathrm{~s}(29) \mathrm{ND}_{3}$ r $1(19)(\mathrm{C} 2 \mathrm{C} 6 \mathrm{~s}(10)$ \\
\hline \multirow[t]{2}{*}{$831 \mathrm{mw}$} & \multirow[t]{2}{*}{$831 \mathrm{~ms}$} & 844 & 844 & 843 & 846 & $\mathrm{C} 12 \mathrm{H}_{2} \mathrm{r}(22) \mathrm{C} 14 \mathrm{~N} \mathrm{~s}(10)$ \\
\hline & & 813 & 809 & 813 & 809 & $\mathrm{NC} 17 \mathrm{C} \mathrm{d}(15)(\mathrm{N} 17 \mathrm{C} \mathrm{s}(11)$ \\
\hline $804 \mathrm{w}$ & $80) 3 \mathrm{w}$ & 800 & 799 & 799 & 800 & $\mathrm{~N} 1 \mathrm{C} s(27) \mathrm{C}_{6} \mathrm{H}_{2} \mathrm{r}(13) \mathrm{CO}_{2} \mathrm{~b}(10) \mathrm{CO}_{2} \mathrm{w}(10)$ \\
\hline $785 \mathrm{mw}$ & $785 \mathrm{vw}$ & 783 & 784 & 784 & 783 & $\mathrm{CO}_{2} \mathrm{~b}(29) \mathrm{CO}_{2} \mathrm{w}(27) \mathrm{CO}_{2} \mathrm{ss}(15)$ \\
\hline $755 w$ & $754 \mathrm{~m}$ & 749 & 750 & 749 & 750 & COD b $(10)$ \\
\hline $728 w$ & $727 \mathrm{~m}$ & 706 & 706 & 706 & 706 & $\mathrm{CO}_{2} \mathrm{~b}(22) \mathrm{CO}_{2} \mathrm{w}(15) \mathrm{CC} / 3 \mathrm{~s}(12)$ \\
\hline \multirow[t]{2}{*}{681 vs } & $679 \mathrm{sh}$ & 683 & 682 & 683 & 682 & $\operatorname{CS} s(32) \mathrm{COD} b(27)$ \\
\hline & $672 w$ & 680 & 678 & 680 & 678 & $\mathrm{COD} \mathrm{b}(32) \mathrm{Cl} 4 \mathrm{O}$ ob(18) $\mathrm{C} 17 \mathrm{H}_{2} \mathrm{r}(10) \mathrm{CO} 19$ ob(10) \\
\hline \multirow[t]{2}{*}{$649 \mathrm{sh}$} & $645 \mathrm{sh}$ & 655 & 651 & 655 & 651 & $\operatorname{CS} s(35)$ \\
\hline & $633 \mathrm{~ms}$ & 635 & 635 & 635 & 635 & $\mathrm{C} 8 \mathrm{O}$ ob(35) CC7C d(25) C8O ib(11) CC8 s(10) \\
\hline $625 \mathrm{sh}$ & $626 \mathrm{vw}$ & 619 & 619 & 619 & 619 & $\mathrm{CSD} \mathrm{b}(78) \mathrm{C}_{12} \mathrm{H}_{2} \mathbf{r}(23)$ \\
\hline $614 \mathrm{~ms}$ & $610 \mathrm{~ms}$ & 596 & 595 & 596 & 595 & $\mathrm{CCO} 20 \mathrm{~d}(18) \mathrm{Cl}_{17} \mathrm{H}_{2} \mathrm{r}(16) \mathrm{CO} 19 \mathrm{ob}(15) \mathrm{NC} 17 \mathrm{C}$ d(12) CO20 t(11) \\
\hline \multirow{2}{*}{$571 \mathrm{vw}$} & \multirow{5}{*}{$528 \mathrm{~s}$} & 586 & 587 & 586 & 587 & $\mathrm{C} 80$ ob(20) $\mathrm{C} 80 \mathrm{ib}(14) \operatorname{CC} 8 \mathrm{~s}(11) \operatorname{CO} 19 \mathrm{ib}(11)$ \\
\hline & & 556 & 556 & 556 & 557 & CC8N d(18) C $140 \mathrm{ib}(18) \mathrm{C} 80 \mathrm{ib}(10)$ \\
\hline $54: 3 \mathrm{sh}$ & & 534 & 540 & 534 & 540 & NC11C d(16) \\
\hline $533 \mathrm{mw}$ & & 525 & 523 & 523 & 525 & $\mathrm{CO}_{2} \mathrm{r}(35) \mathrm{N} 1 \mathrm{C}$ s(32) C8N t(10) \\
\hline $515 \mathrm{sh}$ & & 505 & 500 & 505 & 500 & $\begin{array}{l}\mathrm{C} 14 \mathrm{~N} t(48) \mathrm{COD} b(25) \mathrm{N} 16 \mathrm{D} \text { ob(19) OD } \cdots \mathrm{O} b(18) \\
\mathrm{CO} 20 \mathrm{t}(14) \mathrm{CO} 20 \cdots \mathrm{D} \text { b(12) }\end{array}$ \\
\hline $480 \mathrm{vw}$ & \multirow{4}{*}{$469 \mathrm{~m}$} & 492 & 491 & 491 & 492 & C8N t(70) N10D ob(33) $05 \cdots$ D3[N1] s(10) \\
\hline $468 \mathrm{sh}$ & & 451 & 450 & 451 & 450 & CC7C d(19) CC6C d(16) N10D ib(10) \\
\hline \multirow{2}{*}{$445 \mathrm{vw}$} & & & 436 & & $4: 36$ & $\mathrm{COD} b(61) \mathrm{OD} \cdots \mathrm{O} b(54) \mathrm{CO} 20 \mathrm{t}(42)$ \\
\hline & & 429 & & 429 & & $\mathrm{COD} b(37) \mathrm{OD} \cdots \mathrm{O}$ b(33) $\mathrm{CO} 20 \mathrm{t}(25)$ \\
\hline \multirow[t]{2}{*}{$418 \mathrm{vw}$} & & & 420 & & 420 & $\operatorname{CCO} 20 \mathrm{~d}(13) \mathrm{C} 12 \mathrm{bl}(12) \operatorname{CCS} d(10)$ \\
\hline & & 405 & & 404 & & N16D ob(25) CO19 ib(20) C14N t(19) CCO20 d(15) COD b(10) \\
\hline \multirow{2}{*}{$399 \mathrm{~m}$} & & 394 & 396 & 396 & 395 & $\mathrm{NiC} t(20) \mathrm{C} 3 \mathrm{~b} 2(13) \mathrm{NCC} 3 \mathrm{~d}(12)$ \\
\hline & & 386 & 385 & 384 & 386 & N1C t(29) Ci3 b2(10) NCC3 d(10) \\
\hline $362 \mathrm{w}$ & & 346 & 351 & 348 & 350 & C12 b2(18) \\
\hline $339 \mathrm{w}$ & & 334 & 320 & 334 & 320 & $\mathrm{CCO} 20 \mathrm{~d}(26) \mathrm{NC} 17 \mathrm{C} \mathrm{d}(16) \mathrm{C} 12 \mathrm{~b} 2(11)$ \\
\hline \multirow[t]{8}{*}{$305 \mathrm{w}$} & & 290 & 289 & 292 & 286 & CN16C d(24) NCC3 d (10) \\
\hline & & 261 & 265 & 266 & 261 & $\mathrm{CC} 7 \mathrm{C} d(13) \mathrm{NCC} 3 \mathrm{~d}(12) \mathrm{CN} 16 \mathrm{C} \mathrm{d}(12)$ \\
\hline & & 255 & 257 & 256 & 256 & $\mathrm{C} 12$ b2(28) \\
\hline & & 233 & 230 & 230 & 233 & $\mathrm{C} 3 \mathrm{~b} 1(57) \mathrm{CO}_{2} \mathrm{w}(10)$ \\
\hline & & 211 & 213 & 211 & 213 & $\mathrm{SD} \cdots \mathrm{O} b(12) \mathrm{CC} 14 \mathrm{~N} d(11) \mathrm{CN} 16 \mathrm{C} d(10)$ \\
\hline & & $20: 3$ & 204 & 204 & 203 & SD $\cdots$ O b(14) CC14N d(13) C3 b2(13) CN10C d(11) \\
\hline & & 198 & 198 & 198 & 198 & $\mathrm{SD} \cdots \mathrm{O} b(63)$ \\
\hline & & 176 & 176 & 176 & 177 & CN10C d(24) CCS $d(19)$ \\
\hline
\end{tabular}

"s, Strong; m, medium; w, weak; sh, shoulder.

${ }^{b}$ Contributions to potential energy distribution of 10 or larger, s, Stretch; ss, symmetric stretch; as, antisymmetric stretch; b, bend; st), symmetric bend; ab, antisymmetric bend; ib, in-plane bend; ob, out-of-plane bend; d, deformation; w, wag; tw, twist; $r$, rock; $t$, torsion.

contribution is predicted for a mode at $864 \mathrm{~cm}^{-1}$, and a Raman band at $868 \mathrm{~cm}^{-1}$ is assignable to this mode. In GSD this mode is predicted to move down, with a major $\mathrm{CO} 20 \mathrm{~s}$ contribution at $1322(1332)$ $\mathrm{cm}^{1}$ and a smaller contribution at $1361 \mathrm{~cm}^{1}$, which may be assignable to the $1349 \mathrm{~cm}^{-1}$ band. This situation illustrates the value of having ab initio force fields derived from higher energy-minimum struc- tures of small molecules that model the comparable part of a larger molecule.

The other bands in this region are associated with modes that are generally complex combinations of $\mathrm{C}^{\text {" }} \mathrm{H}^{\mathrm{\alpha}} \mathrm{b}, \mathrm{NH} \mathrm{ib}, \mathrm{CH}_{2}$ w, and $\mathrm{CH}_{2}$ twist (tw), with $\mathrm{NH}_{3}^{+}$rock $(\mathrm{r})$ occasionally mixed in. There is no $\mathrm{CN} \mathrm{s}$ contribution $\geq 5$, except for $\mathrm{C} 8 \mathrm{~N} \mathrm{~s}(7)$ in the $1300 \mathrm{~cm}{ }^{1}$ mode, so no traditional amide III modes 
exist for GSH. Significant NH ib contributions occur for predicted modes at $\sim 1337,1321$, and $1254 \mathrm{~cm}^{-1}$, for which there are assignable bands at $\sim 1335$, 1310 , and $1249 \mathrm{~cm}^{-1}$, but while the second and third of these disappear on deuteration, and make expected contributions at 1068 (1063), 1035 (1051), $1026(1029), 981(982)$, and $962(959) \mathrm{cm}^{1}$, the first does not because it retains its essential $\mathrm{CO} 20$ s character, at $1322(1332) \mathrm{cm}^{-1}$. The Gly $\mathrm{C}_{17 \mathrm{H}_{2} \mathrm{w}}$ modes at 1368 and $\sim 1318 \mathrm{~cm}^{-1}$ in GSH, assignable to bands at 1368 and $1310 \mathrm{~cm}^{1}$, seem to diminish their separation in GSD to modes at 1361 and 1322 $\mathrm{cm}^{\text {'; }}$; this suggests, considering a possible further reduced splitting (from the supposedly parent frequency near $1343 \mathrm{~cm}^{1}$ ), the assignment to bands at 1349 and $1332 \mathrm{~cm}^{-1}$ in GSD. The $\mathrm{C}_{17 \mathrm{H}_{2}}$ tw mode at $1275(1280) \mathrm{cm}^{-1}$ in GSH shifts slightly to 1271

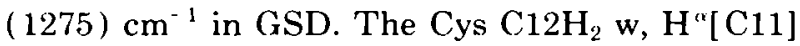
b1 modes remain relatively unchanged: 1260 (1255) and $1174(1170) \mathrm{cm}^{-1}$ in GSH, $1262(1249)$ and 1180 (1182) $\mathrm{cm}^{-1}$ in ( $\mathrm{xSD}$. The $\mathrm{C} 12 \mathrm{H}_{2}$ tw mode at 1201 (1200) $\mathrm{cm}^{-1}$ in GSH increases in GSD to 1216 (1213) $\mathrm{cm}^{-1}$, while a $\mathrm{H}^{\prime \prime}[\mathrm{C} 11]$ b1, $\mathrm{C} 12 \mathrm{H}_{2}$ tw mode at $1125(1122) \mathrm{cm}^{-1}$ retains some of this character in GSD at $1126(1129) \mathrm{cm}{ }^{1}$. The remaining $\mathrm{C}_{6} \mathrm{H}_{2}$ and $\mathrm{C} 7 \mathrm{H}_{2}$ w and tw contributions (mixed with some $\left.\mathrm{H}^{\mathrm{c}} \mathrm{b}\right)$ are well accounted for: 1355 (1351), 1300 $(1290), 1252(1249), 1217(1224)$, and $1149(1143)$ $\mathrm{cm}^{-1}$ in GSH with similar contributions but different $\mathrm{H}^{\text {" }} \mathrm{b}$ admixtures at 1339 (1349), 1320 (1318), 1258 (1239), 1224 (1226), and $1151(-) \mathrm{cm}^{-1}$ in GSD. The $\mathrm{NH}_{3} \mathrm{r}$ coordinates contribute to bands at 1342 (1342), $1291(1290)$, and $1241(1235) \mathrm{cm}^{-1}$ in GSH, and their counterparts in GSD seem to be well accounted for at $1202(1195), 1026(1029)$, and 914 (920) $\mathrm{cm}^{-1}$. Predominant $\mathrm{H}^{\circ} \mathrm{b}$ contributions in GSH modes remain in GSD, although in some cases large changes occur in mode composition: 1342 (1342) to $1320(1318), 1300(1290)$ to $1294(1293)$, $1254(1249)$ to $1258(1239), 1174(1170)$ to 1180 (1182), $1149(1143)$ to $1151(-)$, and 1125 (1122) to $1116(1117) \mathrm{cm}^{-1}$. It is clear that a very complex mixing of coordinates occurs in the normal modes in this region, and simplified designations such as amide III are totally unwarranted. Reality usually requires a more sophisticated view of normal modes of complex molecules.

\section{$1100-700 \mathrm{~cm}^{-1}$ Region}

This region contains the expected skeletal stretch and $\mathrm{CH}_{2} \mathrm{r}$ modes as well as $\mathrm{COH} \mathrm{b}, \mathrm{CSH} b$, and $\mathrm{CO}_{2}$ deformation modes. This leads to significant mixing of these coordinates in most of the modes, with large changes in GSD because of the new mixing with $\mathrm{ND}$ ib and $\mathrm{ND}_{3} \mathrm{r}$ modes.

About the only skeletal modes to retain their essential character and localized frequency are N1C $\mathrm{s}$, which can be assigned at $811(812) \mathrm{cm}^{1}$ in GSH and $800(804) \mathrm{cm}^{-1}$ in $\mathrm{GSD}$, and $\mathrm{NC17} \mathrm{s}$, assignable to $1097(-) \mathrm{cm}^{-1}$ in $\mathrm{GSH}$ and $1090(1098) \mathrm{cm}^{-1}$ in GSD, with the latter probably gaining intensity from its $\mathrm{ND}_{3}$ sb component. The $\mathrm{C} 17 \mathrm{C}$ s mode retains its main form but shifts from $864(868) \mathrm{cm}^{-1}$ in GSH to $890(908) \mathrm{cm}^{1}$ in GSD because of the replacement of $\mathrm{COH} b$ by COD b. Others retain the major skeletal component but change significantly in character and frequency: $\mathrm{CC} 3 \mathrm{~s}$ at $891(885) \mathrm{cm}^{-1}$ in GSH and $847(843) \mathrm{cm}^{-1}$ in GSD; C6C7 at 1068 $(1074) \mathrm{cm}^{1}$ in $\mathrm{GSH}$ and $1004(1000) \mathrm{cm}^{-1}$ in GSD; and $\mathrm{CC} 12 \mathrm{~s}$ at $1006(1014) \mathrm{cm}^{-1}$ in GSH and 962 (959) $\mathrm{cm}^{-1}$ in GSD. Except for $\mathrm{C} 2 \mathrm{C} 6 \mathrm{~s}$, which changes from a major component at 1068 (1074) $\mathrm{cm}^{-1}$ in GSH to a minor component at 847 (843) $\mathrm{cm}^{-1}$ in GSD, and $\mathrm{NC11} \mathrm{s}$, which is distributed in minor proportions at $1125(1122), 1097(-)$, and $927(930) \mathrm{cm}^{-1}$ in GSH and is concentrated at 868 $(860) \mathrm{cm}^{1}$ in GSD, the remaining skeletal stretch coordinates represent small contributions in GSH that either remain small in GSD [cf. C8N s at 905 (917) and $882(885) \mathrm{cm}^{-1}$; and $\mathrm{C} 14 \mathrm{~N} \mathrm{~s}$ at $872(868)$ and $844(831) \mathrm{cm}^{-1}$ ] or drop below our PED limit of 10 in GSD [ cf. CC8 s at $872(868) \mathrm{cm}^{-1}$ and CC14 $\mathrm{s}$ at $\left.1097(-) \mathrm{cm}^{-1}\right]$.

Similar complex behavior is observed in the $\mathrm{CH}_{2}$ $\mathrm{r}$ modes. The $\mathrm{C} \mathrm{H}_{2} \mathrm{r}$ coordinate, which in GSH is distributed between three modes at 1068 (1074), 998 (989), and $811(812) \mathrm{cm}^{-1}$, becomes concentrated in GSD at $800(804) \mathrm{cm}{ }^{1}$. The $\mathrm{C} \mathrm{H}_{2} \mathrm{r}$ coordinate mixes with $\mathrm{CSH}$ b in GSH to give two modes at 956 (952) and $927(930) \mathrm{cm}^{-1}$ and is concentrated in GSD at $941(948) \mathrm{cm}^{-1}$. The $\mathrm{C}_{17 \mathrm{H}_{2}} \mathrm{r}$ coordinate, which in GSH is concentrated in a mode at 1053 (1041), with a small contribution at $590(-) \mathrm{cm}^{1}$, becomes dispersed in GSD to modes at 1069 (1063), $981(982), 679(672)$, and $596(612) \mathrm{cm}^{-1}$. The Cys $\mathrm{C}_{12} \mathrm{H}_{2} \mathbf{r}$ mode, which is found in ethanethiol at 737 $\mathrm{cm}^{1},{ }^{12}$ is split in GSH between modes at $762(764)$ and $745(758) \mathrm{cm}^{1}$, but is further separated in GSD to modes at $868(860), 844(831)$, and 619 (626) $\mathrm{cm}^{-1}$.

As we noted above, the $\mathrm{COH} b$ force constant was determined by the requirement that CO19 $\mathrm{s}$ and CO20 s not shift on deuteration. This results in significant $\mathrm{COH}$ b contributions at 1026 (1030), 864 (868), $825(828)$, and $492(478) \mathrm{cm}^{-1}$ in GSH and $\mathrm{COD} b$ at $888(908), 683(681), 679(672), 503$ (515), and $433(445) \mathrm{cm}^{1}$ in GSD. Assignments 
based on simple disappearance of bands on deuteration are not feasible in this case because of the presence in GSD of new modes at about the same positions [cf. $1029 \mathrm{~cm}^{1}: \mathrm{ND}_{3} \mathrm{r} 1, \mathrm{~N} 10 \mathrm{Dib} ; 860 \mathrm{~cm}^{-1}$ : $\mathrm{NC} 11 \mathrm{~s}, \mathrm{C} 12 \mathrm{H}_{2} \mathrm{r} ; 831 \mathrm{~cm}^{-1}: \mathrm{C}_{12} \mathrm{H}_{2} \mathrm{r}, \mathrm{C} 14 \mathrm{~N} \mathrm{~s}$; and $\left.480 \mathrm{~cm}^{-1}: \mathrm{C} 8 \mathrm{~N} \mathrm{t}, \mathrm{N} 10 \mathrm{D} \mathrm{ob}\right]$.

For the comparable conformation, $\mathrm{CSH} b$ in ethanethiol is found at $869 \mathrm{~cm}^{-1} \cdot{ }^{12}$ In GSH we assign this mode to $927(930) \mathrm{cm}^{-1}$, where it mixes with $\mathrm{C} \mathrm{H}_{2} \mathrm{r}$ and skeletal stretch coordinates. It is also found mixed with $\mathrm{C}_{12} \mathrm{H}_{2} \mathrm{r}$ at 762 (764) and 745 (759) $\mathrm{cm}^{-1}$. In GSD this mode is concentrated at $619(626) \mathrm{cm}^{-1}$, comparable to the $625 \mathrm{~cm}^{-1}$ band found in ethanethiol-SD. ${ }^{12}$

The remaining $\mathrm{CO}_{2}^{-} \mathrm{b}, \mathrm{CO}_{2}^{-} \mathrm{w}$ modes in this region are reasonably well accounted for: 786 (775) and $723(721)$ in GSH and 784 ( 785) and $706(727)$ $\mathrm{cm}^{1}$ in GSD.

\section{Amide V and Skeletal Deformation Region}

The amide $\mathrm{V}$ mode, $\mathrm{CN}$ torsion ( $\mathrm{t}$ ) plus $\mathrm{NH}$ ob, is usually strong in the ir and weak in the Raman, and these modes are well assigned in GSH to bands at $702(691)$ and $692(691) \mathrm{cm}^{-1}$. They disappear in GSD, and their counterparts at 503 (515) and 492 (480) $\mathrm{cm}^{-1}$ are very weak.

Other than the skeletal deformation modes, the CS s mode, which is a strong Raman band at 662 $\mathrm{cm}{ }^{1}$ in ethanethiol, ${ }^{12}$ appears at $679(679) \mathrm{cm}^{-1}$ in GSH (mixed with amide $\mathrm{V}$ of $\mathrm{C} 8 \mathrm{~N} 10$ ), and its shift to $683(681) \mathrm{cm}^{-1}$ in GSD is well predicted. Another $\mathrm{CS} \mathrm{s}$ contribution is present in the $\mathrm{B}_{1}$ and $\mathrm{B}_{3}$ modes at $649(658) \mathrm{cm}^{-1}$ [ as well as a CS s (9) at $643(643)$ $\mathrm{cm}^{-1} \mathrm{l}$, and this appears at $653(647) \mathrm{cm}^{-1}$ in GSD. The same agreement holds for the $\mathrm{NH}_{3}^{1}$ and $\mathrm{CO}_{2}^{-}$ end group modes: $\mathrm{N} 1 \mathrm{C} t$ shifts from $556(549) \mathrm{cm}^{-1}$ in GSH to $395(399) \mathrm{cm}^{-1}$ in GSD, while $\mathrm{CO}_{2} \mathrm{r}$ at $531(520) \mathrm{cm}^{1}$ in GSH remains relatively unchanged in GSD at $524(528) \mathrm{cm}^{-1}$, although it perhaps gains intensity from a new $\mathrm{C} 8 \mathrm{~N} \mathrm{t}$ contribution.

The skeletal deformation coordinates are significantly mixed throughout this region, with only some patterns evident. While CO19 ob contributes at higher frequencies, at $1053(1041) \mathrm{cm}^{-1}$ in $\mathrm{GSH}$ and $1069(1063) \mathrm{cm}^{-1}$ in GSD, as well as at lower frequencies, $590(--) \mathrm{cm}^{-1}$ in GSH and $596(612) \mathrm{cm}^{-1}$ in GSD, $\mathrm{C} 14 \mathrm{O}$ ob and $\mathrm{C} 8 \mathrm{O}$ b contribute only in the lower frequency region. However, $\mathrm{C} 140$ ob mixes with CS s in GSH, at $679(679) \mathrm{cm}^{-1}$, while in GSD it mixes predominately with COD b, at 679 (672) $\mathrm{cm}^{-1}$ [ there is a $\mathrm{C} 140$ ob (9) contribution to the $683(681) \mathrm{cm}^{-1}$ mode ]. On the other hand, $\mathrm{C} 80 \mathrm{ob}$ is dominant in three modes in $\mathrm{GSH}$, at $648(658)$,
625 (624), and $546(549) \mathrm{cm}^{-1}$, retaining this dominance in two modes in GSD, at 635 (633) and 587 (571) $\mathrm{cm}^{-1}$. A CC6C deformation (d), CC7C d mode at $445(446) \mathrm{cm}^{-1}$ in GSH moves to $451(469) \mathrm{cm}^{-1}$ in GSD, perhaps gaining intensity from an N10D ib contribution. The $\mathrm{CCO} 20 \mathrm{~d}$ coordinate contributes to bands at $420(429)$ and $337(350) \mathrm{cm}^{-1}$ in GSH, with contributions at 412 (418) (modified by N16D $\mathrm{ob})$ and $327(339) \mathrm{cm}^{-1}$ in GSD. A strong band at $401 \mathrm{~cm}^{-1}$ in GSH can be assigned to C3 b2, NCC3 d, with a counterpart in GSD at $395(399) \mathrm{cm}^{1}$. The C12 b2 mode is at 353 ( 360$)$ in GSH and at 349 (362) in GSD, and a CN16C d mode stays relatively constant at $296(303)$ in GSH and $289(305) \mathrm{cm}^{-1}$ in GSD.

\section{CONCLUSIONS}

The GSH molecule presents a challenging problem in normal mode analysis because of the variety of different chemical groupings of atoms in its structure: main-chain peptide groups, charged $\mathrm{NH}_{3}^{+}$and $\mathrm{CO}_{2}$ end groups, uncharged side-chain $\left(\mathrm{CH}_{2} \mathrm{SH}\right)$ and end $\left(\mathrm{CH}_{2} \mathrm{COOH}\right)$ groups, and an unusual mainchain $(\gamma$-Glu $)$ structure. In addition, all of the capable groups participate in a complex pattern of hydrogen bonds between the four molecules in the unit cell. Nevertheless, using currently available empirical force fields for the peptide group ${ }^{8}$ and the charged end group, ${ }^{911}$ together with ab initio force fields for the $\mathrm{CH}_{2} \mathrm{SH}$ and $\mathrm{CH}_{2} \mathrm{COOH}$ moieties, it has been possible to obtain very good agreement between calculated and observed frequencies for GSH (the average error for observed bands is about 5 $\mathrm{cm}^{-1}$ ) and to satisfactorily account for observed shifts in the deuterated GSD molecule. This not only enhances confidence in the force fields used, but suggests that these force fields should be substantively applicable to other conformations of this molecule.

More general normal mode treatments of multiple conformations of a molecular system will depend on having reliable conformation-dependent force fields. These will probably be based on molecular mechanics potentials, which we have shown can be rigorously derived from spectroscopic force fields, ${ }^{26}$ i.e., sets of quadratic force constants, whether empirical or scaled ab initio, optimized to observed spectra. This approach has been applied to $n$-alkane chains, ${ }^{2 \tau}$ and is now being extended to peptides.

This research was supported by NSF grants MCB-9115906 and DMR-9110353. 


\section{REFERENCES}

1. Dolphin, D., Avramovic, O. \& Poulson, R., Eds. (1989) Glutathione: Chemical, Biochemical and Medical Aspects. Part A, Wiley, New York.

2. Baillie, T. A. \& Statter, J. G. (1991) Acct. Chem. Res. 24, 264-270.

3. Wright, W. B. (1958) Acta Cryst. 11, 632-643.

4. Görbitz, C. H. (1987) Acta Chem. Scand. B41, 362366.

5. Huber, R. E. \& Edwards, L. A. (1989) in Glutathione: Chemical, Biochemical and Medical Aspects. Part A, Wiley, New York, chap. 2.

6. Rabenstein, D. L. \& Keire, D. A. (1989) in Glutathione: Chemical, Biochemical and Medical Aspects. Part A, Wiley, New York, chap. 3.

7. Laurence, P. R. \& Thomson, C. (1980) Theor. Chem. Acta 57, 25-41.

8. Krimm, S. \& Bandekar, J. (1986) Adv. Protein Chem. 38, 181-364.

9. Bandekar, J. \& Krimm, S. (1988) Biopolymers 27, 885-908.

10. Sundius, T., Bandekar, J. \& Krimm, S. (1989) J. Mol. Struct. 214, 119-142.

11. Qian, W., Bandekar, J. \& Krimm, S. (1991) Biopolymers 31, 193-210.

12. Qian, W. \& Krimm, S. (1992) Biopolymers 32, 15031518.

13. Qian, W. \& Krimm, S., to be published.

14. Qian, W., Zhao, W. \& Krimm, S. (1992) J. Mol. Struct. 250, 89-102.
15. Cheam, T. C. \& Krimm, S. (1989) J. Mol. Struct. (Theochem.) 188, 15-43.

16. Reisdorf, W. C., Jr. (1994) Ph.D. thesis, University of Michigan.

17. Sengupta, P. K., Krimm, S. \& Hsu, S. L. (1984) Biopolymers 23, 1565-1594.

18. Susi, H., Byler, D. M. \& Gerasimowicz, W. V. (1983) J. Mol. Struct. 102, 63-79.

19. Kuczera, K. \& Czerminski, R. (1983) J. Mol. Struct. 105, 269-280.

20. Krimm, S. \& Abe, Y. (1972) Proc. Natl. Acad. Sci. USA 69, 2788-2792.

21. Moore, W. H. \& Krimm, S. (1975) Proc. Natl. Acad. Sci. USA 72, 4933-4935.

22. Krimm, S. \& Dwivedi, A. M. (1982) J. Raman Spectrosc. 12, 133-137.

23. Cheam, T. C. \& Krimm, S. (1986) J. Mol. Struct. 146, 175-189.

24. Snyder, R. G., Hsu, S. L. \& Krimm, S. (1978) Spectrochim. Acta 34A, 395-406.

25. Fraser, R. D. B. \& Price, W. C. (1952) Nature 170, 490-491.

26. Palmö, K., Pietilä, L.-O. \& Krimm, S. (1991) J. Comput. Chem. 12, 385-390.

27. Palmö, K., Mirkin, N. G., Pietilä, L.-O. \& Krimm, S. (1993) Macromolecules 26, 6831-6840.

Received February 25, 1994

Accepted April 25, 1994 